\title{
Creating Virginia: The role of John Lederer in the transition of western Virginia from a wilderness into a colony
}

Richard Jason Burns

West Virginia University

Follow this and additional works at: https://researchrepository.wvu.edu/etd

\section{Recommended Citation}

Burns, Richard Jason, "Creating Virginia: The role of John Lederer in the transition of western Virginia from a wilderness into a colony" (2006). Graduate Theses, Dissertations, and Problem Reports. 690. https://researchrepository.wvu.edu/etd/690

This Thesis is protected by copyright and/or related rights. It has been brought to you by the The Research Repository @ WVU with permission from the rights-holder(s). You are free to use this Thesis in any way that is permitted by the copyright and related rights legislation that applies to your use. For other uses you must obtain permission from the rights-holder(s) directly, unless additional rights are indicated by a Creative Commons license in the record and/ or on the work itself. This Thesis has been accepted for inclusion in WVU Graduate Theses, Dissertations, and Problem Reports collection by an authorized administrator of The Research Repository @ WVU. For more information, please contact researchrepository@mail.wvu.edu. 
Creating Virginia: The Role of John Lederer in the Transition of Western Virginia from a Wilderness into a Colony

\title{
Richard Jason Burns
}

Thesis submitted to the

Eberly College of Arts \& Sciences

at West Virginia University

in partial fulfillment of the requirements

for the degree of

\author{
Master of Arts \\ in \\ Sociology
}

Ronald Althouse, Ph.D., Chair

Fred Prichard, Ph.D.

Anna Elfenbein, Ph.D.

Division of Sociology and Anthropology

\author{
Morgantown, West Virginia \\ 2006
}

Copyright 2006 Richard Jason Burns

Keywords: John Lederer, Sir William Berkeley, western Virginia, land expeditions 


\title{
Abstract \\ Creating Virginia: The Role of John Lederer in the Transition of Western Virginia from a Wilderness into a Colony
}

\author{
Richard Jason Burns
}

This thesis seeks to explore and explain the role of John Lederer, a German physician and expedition leader, in the creation of the colony of Virginia. Lederer led three expeditions into the western mountains of Virginia in the years 1670-71, and was the first European to document his expeditions in writing. Sir William Berkeley, Governor of Virginia, commissioned him to explore the western frontier of Virginia in hopes of finding a short route to the East India Sea. The immense commodities, trade, and settlement possibilities within the western Virginia region eventually overshadowed this initial goal.

Following the three expeditions, Lederer's expedition journals were translated from the original Latin texts by Lord William Talbot, Baronet and published in London in 1672. The purpose of publishing the texts was to generate public and political interest in the colony. By doing so, Talbot gained much esteem for himself in the House of Lords and Berkeley gained much renown as one of the founders of the Commonwealth of Virginia, but Lederer gained little with posterity except status as a man of mystery.

This thesis will show, however, that these three men--Lederer, Talbot, and Berkeley-worked in a triumvirate of information that supported the development of the commonwealth. Virginia's future property, resources, and perils were shadowed forth in the texts of Lederer which presented valuable information concerning the nature of the wilderness and of the Native American population that continually threatened the colony. By using that information, Berkeley was capable of instituting policies and creating institutions that would help generate revenue and security in the colony. Further, Talbot's publishing of the expedition journals attracted many in pursuit of a new life to settle in the colony of Virginia. 


\section{Dedication}

This thesis is dedicated to my parents, Richard "Jake" and Linda "Maude" Burns, who have always said I could accomplish anything. Also, to my brother Matthew and sisterin-law Shirley, who are an inspiration and a bottomless source of information. And finally to my best friend John Mullins, who kept me from giving up, and who has been there with me every step of the way.

I would also like to thank my committee, Dr. Ron Althouse, Dr. Fred Prichard, and Dr. Anna Elfenbein for taking the time and interest in John Lederer and helped me get this thesis finished. In addition, I want to thank Kelly Diamond of West Virginia University's Wise Library for her assistance with grammar and citation. Finally to Professor JoAnn Dadisman, who inspired me to believe in the mountains again...

And thanks to every one of my co-workers at WVU Mountainlair, who keep me laughing and help me realize the world is still a fun place. 


\section{Table of Contents}

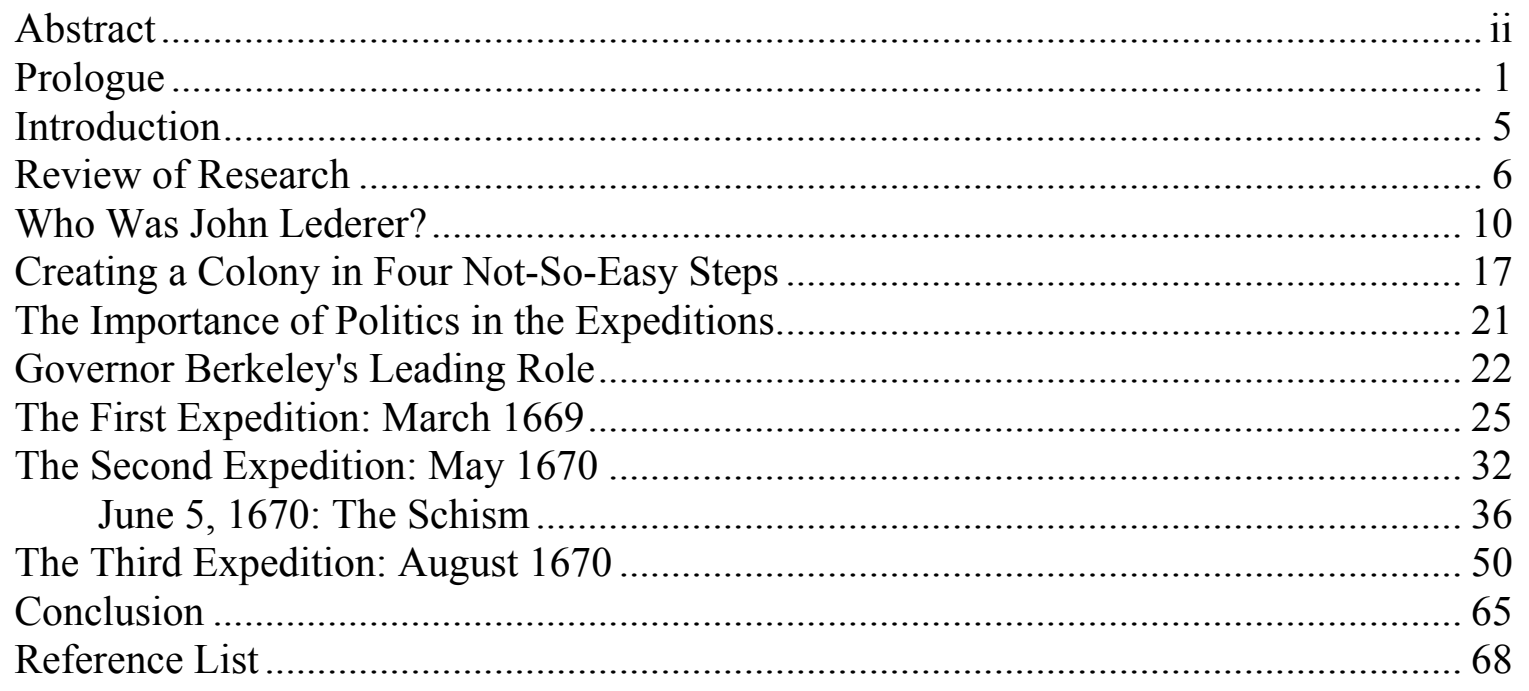




\section{"Power is not an institution, and not a structure; neither is it a certain strength we are endowed with; it is the name that one attributes to a complex strategical situation in a particular society."--Michel Foucault}

\section{Prologue}

This research began as an investigation of the social organization of survey teams in Virginia prior to 1790. However, the theme eventually developed into a look at the formation of property and social economy in Virginia through the designation of land grants and the exploration of them. These land grants were a vital part of the social growth of Virginia's social and economic growth. Land grants preceded land surveys, and were an effort to document the potential investment for England's aristocracy and the potential political economic development in Virginia. The context of the thesis argument rests on historical documentation. These documents are either part of, based on, or contemporary to John Lederer's published expedition journals from 1672 (Alvord \& Bidgood 1912). These documents showed Lederer's route, recorded Lederer's observations, and reported the theories that Lederer had concerning the mountains, conditions, and resources of western Virginia. This argument states that Lederer was a tool of the aristocracy, who through his work set the stage for the creation of the economy of Virginia by supplying the colony with information it needed to explore and exploit the western mountains of Virginia, and in turn this created a economically viable English colony in Virginia.

This thesis is an effort to document social economic development through the exploration of investment potential in the colony of Virginia. Lederer's journals and their contemporary documentation were evidence of this potential. The methodology of 
the research involved collecting existing documentation on the expedition, reading commentaries that were written about Lederer and his work, and scrutinizing them for veracity, historical accuracy, and relevancy to the argument.

In addition to being a study of the land's potential and viability, the expedition journals were also a measure of Lederer and his relationships with others. Despite his vast knowledge and references, his work as an expedition leader has been the subject of skepticism. The veracity of his observations has been debated by some scholars, but other scholars defend his observations through the use of logical reasoning. Though over three centuries have passed since Lederer's expeditions, the attitudes toward them have changed little. The scholarly debate over Lederer's expeditions is still raging, but his value as a social observer is undeniable.

The creation of the colony of Virginia was the creation of a political and social economy. Through the use of knowledge and intelligence, John Lederer became an instrument of that colony. His skills gave the western mountains of Virginia structure, helped the colony design a strategy for investment, and turned the wilderness into an organized commodities market. Lederer's skills included his training as a physician, and his ability with languages. In addition, Lederer's scientific background gave him good observation skills, as well as the ability to hypothesize. Using these skills, Lederer was capable of reporting valuable information concerning the wilderness, the Native Americans, and the natural resources of the western mountains of Virginia.

This information was stark evidence to the upper genteel classes of Virginia and England concerning the investment potential of the colony. Through this information, the nobility of the realm was induced to invest funds in the future of the colony, and 
thereby sanctioned the creation of the colony's economic and social structure. Lederer, as an observer, provided colonial Virginia with a view of the possible monetary gain to be had from investment in the colony. This was distinctive information concerning the viability of the land, the trade routes, the commodities available, and the dangers posed to those traveling or wishing to settle the land. It was a common-sense study of the worthiness of the land, and it represented potential wealth to the English.

In order to mobilize economic development, Lederer and others who followed his example used expedition journals as a form of technology. The expedition journals were not travelogues--they were distinct scientific information concerning the land, and the purpose of this information concerned the thematic evolution of the wilderness into organized, valuable property and the creation of Virginia's economy. In addition, they included instructions on how to traverse the region, how to prepare an expedition, and what dangers and commodities could be found there. In fact, Lederer's journals were the first to record an expedition into the western mountains of Virginia. Following his lead, many other expeditions were made into the region - including expeditions by George Washington. The close examination of Lederer's journals and contemporary texts allows for the assessment of Lederer's role in the creation of the social economy of the colony of Virginia.

The thesis follows a distinct pattern of construction, beginning with a foundation built upon previous research by earlier scholars of Lederer. Within the review of research, it is possible to see the previous research and scholarly record that influenced the blueprint of the argument. This blueprint is based upon the authoritative opinions of many previous scholars of Lederer that had created his mythology. The building blocks 
of the argument were made from a mixture of previous scholarly research and new theories and ideas about Lederer. Some of these new ideas formed after reading research and theories concerning Lederer and the contemporary social record of the time. All of this information was used to build upon previous research, and argued for Lederer's importance during the construction of the Virginia colony.

While past researchers had given credence to one aspect or another of Lederer's expeditions, it is my thesis that sought to answer the six basic interrogatives concerning John Lederer and his time in Virginia -- who, what, where, when, how, and why. The chapters of the thesis seek to answer these questions.

The initial chapters - the Introduction, Review of Research, and the biographical sketch Who was John Lederer? show who Lederer was and delve into his personal mythology. These chapters show that Lederer was an accomplished doctor and expedition leader, but also show how his work has been perceived and debated by scholars.

The next chapter is Creating a Colony in Four Not-So-Easy Steps. This chapter shows what specific conditions had to be present for the creation of the Virginia colony to happen. This chapter explains how Lederer's work coincided with the foundations of the colony of Virginia.

The chapters titled, The Importance of Politics in the Expeditions and Governor Berkeley's Leading Role delve into the importance of politics in expeditions. This is shown through the work of Sir William Berkeley, Governor of Virginia, and Lord William Talbot Baronet. These men worked closely with Lederer and were significant in working towards the creation of the Virginia colony. 
The next three chapters are concerned with Lederer's three expedition journals. These chapters are annotated versions of the English translation of Latin originals by Lederer. First published in 1672, these journals were important documentation of the western mountains of Virginia. They were documentation of commodities, dangers, and trade possibilities in the western Virginia region. These documents became the basis for later reports from the Appalachian frontier, as well as the basis for investment in the colony.

In the Conclusion, the ideas are attached to a single idea -- the social economy of Virginia. While the initial plan may have been to discover a short route to Asia by traveling over the Appalachian Mountains, Lederer showed that there was more to the mountains than a pathway. He discovered a whole new world of possibilities for the future of Virginia.

\section{Introduction}

Among the colonial explorers of Virginia, a German expedition leader named John Lederer stands out. Lederer was the first explorer to produce a written description of the Appalachian Mountain region to the English-speaking world. He led a total of three expeditions into the western mountains of Virginia in the early 1670s and recounted his experiences in a volume entitled The Discoveries of John Lederer In Three Several Marches From Virginia, To the West of Carolina, and Other Parts of the Continent: Begun in March 1669, and ended in September 1670. Together with a General Map of the Whole Territory which He Traversed (Cumming and Rights, 1958, 1). His friend Lord William Talbot published this text in England in 1672. Using this text and other 
documentation, it is possible to re-examine John Lederer's role in the formation of the Virginia colony.

Lederer lived and worked during a pivotal time in Virginia. He was involved in the massive task of exploring the western mountains of the Virginia colony, and furthering its western settlement. His three expedition journals recorded his journeys into the western mountains of Virginia during 1670 and 1671 (Cumming \& Rights 1958). ${ }^{1}$ They revealed a time when Virginia was a fledgling colony on the edge of wilderness, and they produce a picture of what economic and social arrangements were important in the creation of Virginia.

\section{Review of Research}

Despite his obvious importance, research of Lederer's colonial exploration has been sparse. The accounts of early explorers were somewhat unreliable, and the commentaries of scholars who have studied these accounts were freighted with error and fraught with bias. ${ }^{2}$ It was thus a confusing process to form a distinct idea of what exactly to believe, but this thesis seeks to form a clearer picture of Lederer's expeditions, their role in the creation of Virginia's social economics, and how the colony functioned as a business enterprise of England.

This research follows that of earlier scholars who hold differing opinions about Lederer's contributions to history and society. In addition to Lederer's expedition

\footnotetext{
${ }^{1}$ Sadly, Lederer's original Latin account of his expeditions is now lost to history, but an English translation still exists. Lederer's Latin reports were translated into English in 1672 by Sir William Talbot of Maryland, and published in London that same year. The original Latin expedition journals are lost, but could still exist today in one of two places. They could have been taken to London with Talbot when he had the translation published, or Lederer could have taken them to Germany with him when he traveled there later in his life. However, they could also have been destroyed in a fire with other county records in Calvert County, MD in 1882 (Cumming \& Rights 1958).
} 
journals, many scholarly sources offered information. Of the many documents and works on Virginia's colonial period, there are few individuals who directly mentioned Lederer in their research. The ones cited in this thesis are Clarence Walword Alvord, Lee Bidgood, William P. Cumming, Douglas L. Rights, Richard B. Drake, Stephen Adams, and Henry Savage, Jr. As a rule, these scholars agreed, but there were some main points on which they disagreed.

There were many disputed points in Lederer's expedition journals. For example, no scholar was entirely certain of Lederer's travel route and observations. However, Richard B. Drake, in his A History of Appalachia (2001), was willing to mention and then completely discard Lederer's entire explorations of the western mountains of Virginia. Despite the fact that Lederer was the initial explorer to completely document his expeditions into the Appalachian Mountains, Drake denounced Lederer's writings as worthless, and dismissed Lederer's journeys as pure fallacy rather than the informative undertaking they actually were. Without Lederer, the expeditions would never have taken place, the journals would never have been published, and the creation of the Virginia colony would have been put on hold until some other explorer took up the challenge of exploring the western mountains of Virginia.

In Clarence Walword Alvord's and Lee Bidgood's The First Explorations of the Trans-Allegheny Region by the Virginians 1650-1674 (1912), John Lederer's expedition journals are related in their entirety. In fact, they are cited by several of the other scholars mentioned here. For these two scholars, there was only one question concerning Lederer's journeys. Alvord and Bidgood labeled Lederer's travel route conjectural, but

\footnotetext{
${ }^{2}$ Please see the reference list for a full list of resources used.
} 
accepted the rest of Lederer's expedition journals as the truth. They realized that there was value in every social observation despite its possible unintentional or intentional error. Like other scholars of Lederer, their only skepticism dealt with the route that Lederer took through the mountains. For example, they stated that Lederer's observations of the Native Americans sounded similar to those of more southerly Native American tribes, and therefore the two scholars claimed Lederer took a more southern route than the one he claimed.

In Discovering America 1700-1875 (1979), Henry Savage, Jr., stated that Lederer was more valuable as a social record than as an explorer. Lederer's journals were full of seemingly fantastical observations about his second journey, but even the "fantasy" aspect revealed much about the society of Virginia at that time. Lederer was not the only explorer to "fantasize" about the land during an expedition (Alvord 1912). ${ }^{3}$ Because of that, Savage stated that Lederer's role was as a "beacon for his society" (Savage 1979). Savage explained how Virginians treated incoming foreigners, explorers, and how colonial Virginia society functioned as a sociological whole. His texts also have recorded the mindset of the time, and how the society coped with having to create a commonwealth.

One of the more objective sources was Stephen Adams's The Best \& Worst Country in the World: Perspectives on the Early Virginia Landscape (2001). It gave Lederer the benefit of the doubt, and tried to explain Lederer's seemingly fantastical observations through logical reasoning. "No smoke without fire" was the theme in this

\footnotetext{
${ }^{3}$ The hypnotic effect of the environment of the western mountains of Virginia could be the reason so many expeditions reported strange "facts" such as Lederer's vision of the Atlantic Ocean from the summit of the Blue Ridge. Fellow explorers Thomas Batts and Robert Fallam had similar delusions on their expeditions.
} 
text. Adams stated that Lederer did take the route that he claimed to have taken, and that he observed everything he claimed to have observed. Adams treated Lederer's Discoveries as truth, rather than fiction.

In the aforementioned texts, five of the six gave at least some quarter to Lederer's honesty. Drake, for all intents and purposes, probably found it difficult to place Lederer among the more studied figures in colonial history. When writing a "history" of a place, there are certainly bits and pieces that fall through the cracks (not always as intentionally as this). Drake more than likely found Lederer a moot point in the argument, especially when other later (and more popularly studied) explorers such as Batts and Fallam gave much more information (though Lederer is every bit as reliable). However, Drake has done Appalachia a disservice in his writing by labeling Lederer's observations as fallacies. Drake contributed a good deal of information about the colony of Virginia, however. He related an overall history of it, and portrayed social aspects that were necessary to the function of the colony at this time in history.

William P. Cumming and Douglas L. Rights gave a more complete picture of John Lederer (Cumming 1958). They collected a volume of information concerned with John Lederer in the time after his three expeditions into the mountains. It was from this work that John Lederer came to life. He was shown not as an explorer, but as a surgeon and a citizen of the colonies. This text contained a large amount of biographical information about Lederer's life. It explained where Lederer came from, what he did following the expeditions, what possibly happened to his original Latin journals, and where he eventually went following his time in Virginia. Also included in this text were 
essays concerning the various Native American tribes Lederer met. Within these essays, the Native Americans Lederer wrote about were discussed in detail and more evidence was given to support Lederer's travel routes through the Appalachian Mountains.

Of course, all the Lederer scholars set a good precedent with the exception of Drake. By asking questions and putting forth theories, these scholars delved into the various types of information that were found within Lederer's journals. In their texts, they proceeded to explore and explain the wilderness of Lederer's travels and observations. In a sense, they were latter-day Lederers, who were scientifically sifting through large amounts of information--and creating theories.

Using their texts, it was possible to explore deeper into the areas they had explored, and follow tangents they mentioned. Each of these scholars had a unique take on Lederer. In addition, it was interesting to note that the scholars disagreed with the way that Lederer gathered his information about his expeditions, but none of the scholars except Drake disputed the validity of that information.

\section{Who Was John Lederer?}

Some critics have described Lederer as a phony, a liar, or an unobservant flake. Other scholars and contemporaries of Lederer find him admirable, a pioneer in his field, and a victim of social politics. In dealing with scholarly texts concerning Lederer and his work, it is important to note what is fact rather than to speculate. For example, Lederer was part of the western Virginia exploration, and he was the first European to explore and record his expeditions into the western mountains of Virginia. He was an

was so hypnotic that Batts thought he saw the sails of ships (Alvord \& Bidgood 189). 
exceptionally talented physician (Cumming \& Rights 1958), ${ }^{4}$ a noteworthy scholar, an observer of social conditions, and a German who found himself on the wrong side of "polite" Virginia society. He was a well-educated and skilled explorer who spoke German, English, several Native American languages, and Latin. In addition, he had the skills and Native American connections necessary to traverse the western Virginia region (De Hass 2000), ${ }^{5}$ and further he knew which tribes of Native Americans were welcoming to the Europeans and which ones were not. He also knew about the necessities of traveling in the mountains--what food stores would last the trip, how many guides to take, and which directions to travel. Unlike his contemporary explorers, Lederer was not interested in owning the land himself--he was interested in the job of exploring the land for his benefactor, Sir William Berkeley, Governor of Virginia (Alvord 1912). ${ }^{6}$

During the pre-industrial seventeenth century, populations of people (such as the yeomen) were on the move, and there was an increasing need for money to finance wars that England was involved in throughout the world. In order to generate revenue, many European governments built mercantile companies under the guise of colonies. In England, they set up land companies that served the king's interests, and in return the land company's board of directors was allowed trading privileges within Virginia. The colony of Virginia was a business enterprise of England, and Berkeley was essentially the business manager.

\footnotetext{
${ }^{4}$ John Lederer graduated from the Hamburg Academic Gymnasium in 1662, where he studied medicine (Cumming \& Rights 1958).

${ }^{5}$ The Germans, by joint language and culture as William Penn, were treated amicably by the Native Americans out of respect for the founder of the Pennsylvania colony who the Native Americans admired (De Hass 2000).

${ }^{6}$ Despite his qualifications, Lederer was not Berkeley's first choice for the expeditions into the mountains. That honor belonged to Abraham Wood. The first European to enter western Virginia, Wood traveled into the region in 1651 and claimed to have reached the Mississippi River (Alvord 1912).
} 
One aspect of the business of colonizing Virginia was the domination of trade markets. Also, it created a way for the government to ensure the safety of the citizens. Without the Crown's military support, there would have been no safe haven in the colony of Virginia for settlers or traders. Threats from Spain and other rival European nations, Native American attacks, and the dangers of wild animals were all hazards Virginians had to face. In order to ensure the safety of its colonial trade markets and its citizens, a system of policing was set up by wealthy English political officials.

As an expedition leader of Germanic origin, ${ }^{7}$ Lederer was almost neutral within this system of political control. He was neither a wealthy politician nor was he an English citizen. He was an intellectual. He was schooled in medicine and scientific observation, and within the colonial system he was capable of identifying elements that lesser-trained individuals would not. He had finesse with languages, and was a liaison between Virginia's colonial society and the frontier. Because of this, his journals contained qualitatively better information than was previously available. Using his skills and knowledge, Lederer broadened society's vision of the wilderness. The products of his labors, his three journals, were initially published as a way of promoting land speculation and settlement in Virginia. These journals reported the productivity and viability of the land. In addition to stimulating interest in land speculation and exploration in the Virginia colony, they also made the English common people more aware of the possibilities of a new life within Virginia's western mountains.

\footnotetext{
${ }^{7}$ According to Encyclopedia Britannica (2005), the German Confederation did not exist as a separate nation until 1815 . However, all texts and scholars--including contemporary letters of the time--refer to Lederer as a German.
} 
The English nobility was interested in investing in profitable business ventures-and at the time the most popular were colonial futures. These futures involved everything from land speculation to agriculture. The creation of a viable colony, such as Virginia, was a tempting proposition for the English nobility. The colony of Virginia not only created goods and generated trade, but it also created taxable goods. The capacity for wealth in the new colony was ultimately irresistible to the English--and the more enthusiastic the nobility was about a colony, the more likely they were to invest in it. Therefore, Lederer's journals became the basis for investments in the colony's future. The knowledge that Lederer brought back in his expeditions served as a documentation of the land's potential--and that's what interested the nobility most. In order to interest investors in Virginia, there had to be a set of expectations. The investors wanted to know exactly what they were getting for their money.

In addition to showing the prospects of investments, Lederer's journals served as a model of reporting expeditions. Many other expedition leaders would follow Lederer-Batts and Fallam, George Washington, et al.--and they all used the same method of recording their observations in journals. Lederer was the first to report a sense of recognition and appreciation of the land's value through the use of daily transcripts of his experiences in the mountains. His was the first step to the commodification of the region. He discovered what others would later re-discover.

Lederer was a trained physician (Cumming \& Rights 1958), and therefore had scientific and medical training. He had the necessary training to report on his travels objectively, and he also had the ability to hypothesize about what he observed.

Noticeably, Lederer became exponentially more adept in his observations, and he became 
bolder in creating theories and giving advice. In the three epilogues to his expedition journals, Lederer plainly showed this trait. His advice on traveling into the region and on how to communicate with the Native Americans of the time plainly shows that Lederer thought beyond the initial experience. He knew others would follow in his footsteps, and he also knew his work would be reviewed by others. In the three epilogues, Lederer sought to distill the knowledge he had acquired into a usable form for those who would come later. This exploration of attained knowledge over time revealed a certain methodology in Lederer's thinking. He created order in the world he observed through the use of his scientific background, and sought to help others through his work.

Lederer's work as an expedition leader for the Virginia colony was the result of the governor's interest in a route to the East India Sea via a route through the Appalachian Mountains. Governor Berkeley favored Lederer, and contracted him for three expeditions into the western mountains of Virginia during 1670-71. The goal of these expeditions was to find the value of the wilderness by discovering the commodities available. The revenue produced was initially monetary, but eventually led to social and cultural value as well. There was a corresponding-almost parallel-growth between economic prosperity and social influence. Using the knowledge Lederer gathered, Berkeley was then capable of determining how to control the use of the natural resources for the best interest of Virginia. Once the value of these commodities was determined, the land was capable of being processed into property. This property was then used or sold to create revenue, which in turn was used to fund social projects within the colony. Once social order was created, the transmutation of wealth was possible. 
The formation of a social order in the colony was of the highest importance to Berkeley (Talpalar 1960). ${ }^{8}$ He was a key figure in the initial wars between Native Americans and the European colonists in March 1622. However, a treaty in 1646 brought eventual peace to the Tidewater. By 1651, Berkeley stated, "The Indians, God be blessed, round about us are subdued" (Talpalar 91). Berkeley set the stage for what would become the social economic order of the Virginia colony. His legal, political, and social knowledge combined with information obtained from Lederer's expeditions provided for the domination of the land and its indigenous peoples. It also allowed for the creation of viable economic markets. As Virginia's colonial economy became more stable, there was a corresponding--almost symbiotic--growth of society. Economic wealth was essential to the creation of the Virginia social order and that all began when Lederer determined what commodities were available in the region.

However, if it were not for Sir William Talbot, Baronet, John Lederer's texts might never have been published, the journals would have faded into the mists of history, and the growth of the Virginia colony would have been stunted. Despite Berkeley's interest in the settlement of the Virginia backcountry, Talbot deserves the credit for gaining political interest in western Virginia. Talbot was the Secretary of Maryland Province, and in addition he was the cousin of Governor Charles Calvert of Maryland, who was the son of Cæcilius Calvert, 2nd Baron Baltimore. Talbot's political network allowed him to further his interests - which included Lederer. In June 1671, Talbot inherited a barony in Ireland from his father, and later left Maryland to return there

\footnotetext{
${ }^{8} \mathrm{He}$ has been called "the progenitor of the sociology of the South." Governor William Berkeley was an aristocrat, but his distance from the royal workings of England gave him the opportunity to become protaganist in the formation of the Virginia colony (Talpalar 1960).
} 
(Cumming \& Rights 1958). While in the England, Talbot sought out Anthony Lord Ashley, Baron Ashley of Wimborn St. Giles, who had great power in the House of Lords. Riding the wave of interest in the possible route to Asia over the Appalachians, Talbot published Lederer's expedition journals in London. The book created fervor among possible investors, and the common citizens of England were very interested in land they could purchase for themselves. This action brought Talbot much political esteem in England, and made Lederer's journals a part of British as well as Virginia history. Berkeley, Talbot, and Lederer each had their role in the creation of the Virginia colony. Through their efforts, the colony of Virginia transitioned from a backwater settlement into a profitable business venture. The combined knowledge of Lederer, Berkeley, and Talbot provided the ability for domination, gave Virginia the ability to select and communicate within the new environment, showed it where to invest its time and resources, and where to locate the bases of operations (forts). Following a Native American attack in 1644, Berkeley ordered the construction of numerous forts along the border between the colonists and Native Americans (Adams 2001). Many of these forts were later stops for expeditions into the region, including Lederer's. In addition, this combined knowledge provided the foundation for mapping and planning the exploitation of the environment. The use of this knowledge implemented policies that transformed the community, created settlements, and formed viable trade markets in the colony.

Lederer, Berkeley, and Talbot each used their knowledge in different ways, but each furthered the interests of the colony. Virginia gained its knowledge through expedition leaders like Lederer. He was the root of the colony's "learning process." Berkeley in turn used that knowledge to designate and implement the colony's functions 
and settlements. Talbot did his part by currying political favor and gaining funding for this institution within the House of Lords in England. This triad of knowledge made the complex process of creating the Virginia colony possible.

\section{Creating a Colony in Four Not-So-Easy Steps}

The colony of Virginia had four main aspects in its creation, and each of them had its seed in the expeditions of Lederer. These four aspects were land, people, trade markets, and a social order by which to function. The colony could not have existed if any one of these aspects was lacking.

The first step in creating Virginia was finding the land. By Lederer's time, the land in the Tidewater area of Virginia was already claimed, and the English settlements needed to expand into the western territory of Virginia. Virginia had a great deal of land within its borders, but it was not all arable or safe to live in.

The main challenge was creating civilization out of wilderness, and property out of wild land. Wilderness has no boundaries and no material value on its own. The Virginia colony was only profitable once the land had been cleared, plowed, and planted. Arable land for crops, homes, and trade routes had to be found before the land was given any monetary value (Talpalar 1960). When arable land had to be found, when the natural resources and trade routes through a region had to be discovered, and when the potential threats to colonization had to be identified--Berkeley called upon the expedition leaders

like Lederer. By tying together the mechanisms of land, commodity, and knowledge, it is possible to determine how the colony of Virginia was created. In addition, it is possible to see how men like Talbot aided the creation of the colony by publishing a politically 
well-received document such as Lederer's expedition journals. The publication of this document and those like it resulted in a growing interest in land grants and speculation.

Land grants were allocated to many wealthy and influential members of the English aristocracy. However, this land had only been allocated to them on paper. Land accessibility, not availability, then became the issue. The land grant was still wild, full of Native Americans, dangerous animals, unknown natural resources, and covered with unknown species of vegetation. To add to these conditions, the King of England imposed taxes on the land grant. In England, a law was also passed that stated that once the land was made arable; the landowner needed the King's permission for anything he wanted to plant or produce on it.

Of course, there were many stipulations to be met before being considered for a land grant. The land grantee had to be an English citizen, take the oath of allegiance to the King of England, and when the grant was received, it was the grantee's responsibility to protect the land from encroachment by enemies of the English (Talpalar 1960). In reality, the land grant was only a potential source of income for the grantee. There was no guarantee of profit from the land, and no guarantee of being able to settle it or live on it. As Lederer discovered in his expeditions, this potential wealth was not always easy or sensible to pursue. Lederer had noticed that the opportunities for gaining wealth in the western Virginia mountains were limitless--but the ruggedness of the land and its unknown dangers kept many from attempting its settlement.

However, land in Europe had become increasingly difficult to find. It had been divided throughout the centuries through inheritance, and (more importantly) the commons that had once been the only available grazing land were being closed in many 
countries. Any land that was available for sale was expensive (Sweet 2003). Citizens who sought a freedom from this suffocating land deficiency in Europe found their way to North American colonies such as Virginia where land was available.

The second step to creating Virginia was finding citizens willing to live in Virginia (Sweet 2003). ${ }^{9}$ England and other overpopulated European nations were the source of these colonial citizens, but not all of them came voluntarily. Many were deported criminals, or they were poor people from large cities who indentured themselves to find a better situation in Virginia. Many of the colonists, however, were yeoman farmers. The yeoman farmers of Europe were a key demographic for land companies wanting to colonize Virginia. The Virginia Company--a land speculation company in the New World--based the colonization of Virginia on the "growth of an independent yeomanry" (Talpalar 1960). In Europe at this point in history, yeomanry was a way of life for most of the population. However, the yeoman farmers were seen as a threat to society in England, mostly because evicted tenant farmers were filtering into the larger cities. The overpopulation of large towns such as London led to high crime rates, and contributed to shortages of food and adequate housing (Adams 2001).

Yeomanry was based in a peasant culture, and saw land ownership as its life source and future well being. This culture was based in self-sufficiency and subsistence, and had already mastered the art of cloth weaving, dying wool, soap making, horticulture, quilt making, husbandry, fermentation of alcohol, agriculture, basket weaving, woodcarving, and metallurgy (Drake 2001). A scholar (or any citizen of) the

\footnotetext{
${ }^{9}$ England found an outlet for its surplus products and its "waste" people that had saturated the Old World markets. This process in turn changed the products and people from overburden into revenue-producing commodities. In addition, they were creating not only a new English social order, but creating products that England hoped would replace those from other parts of the globe (Sweet 2003).
} 
Appalachian culture can see the parallels between yeoman culture and what has become known as Appalachian culture. This subsistence-based yeoman culture was constituted by a people strong enough to withstand the aspects of living in the western Virginia mountains, and became the basis for the colonial economic structure that was to come. They would not only become taxable population, but would also provide a market for surplus English goods. In addition, they would create New World goods for the European trade markets.

The system of trade and the formation of commodities to supply the colony was the third step to creating Virginia. Initially, Virginia had trouble forming a trade system because it based its possible commodities on crops grown in the same latitude in Europe. These included olives and wine, which England had to import from the countries surrounding the Mediterranean Sea (Adams 2001). However, it was soon realized that revenue was more likely to be found in the fur trade and timber industries, as olives and grapes were not acclimated to the climate of Virginia.

The fourth step of the creation of Virginia was the establishment of a social order by which the colonial society could function. In Europe, the society was based on feudalism, and Virginia based its social order on a similar system. Berkeley installed a social order based on the ideas of the plantation, the county, and the parish. Each of these had a particular role to play in the colony. The plantation was the economic force. The county led the legislative operations, judicial system, and the military. The parish held all the ecclesiastical, or religious, power (Talpalar 1960). Berkeley's formation of towns, trade routes, and diplomacy with the Native Americans gave rise to the social order in Virginia. However, none of the trade routes, diplomacy, or towns could have 
ever existed without the efforts of expedition leaders like Lederer who explored the territory of Virginia and reported his discoveries to the governor.

\section{The Importance of Politics in the Expeditions}

Politics played a large role in every expedition into the Virginia frontier.

Berkeley had proposed other expeditions prior to Lederer's, but they were denied funding and support by the British crown because of their potentially disastrous international effects (Alvord \& Bidgood 1958).

However, there had been a change in the management of Virginia in 1671, and Berkeley gained support for his venture via political maneuvering. He wrote a letter to Lord Arlington, who was a member of the House of Lords and a good friend of Charles II, then King of England. In 1671, Charles II had granted Arlington, along with Lord Culpeper (another close friend of the King's), the entire colony of Virginia. This action, although extremely generous, caused Virginia to lose its "royal colony" status, and England lost its ability to give land grants in Virginia for thirty-one years (Talpalar 1960). Because of this shift in power, Berkeley approached Arlington (instead of the Crown) for permission to make an expedition into the western mountains of Virginia. In his correspondence to Arlington, Berkeley put forward his ideas for a journey into the western mountains of Virginia. His plan for this expedition was to enter the mountainous region himself with an army of two hundred men (to ward off the Native Americans and the Spanish--he makes no reference to the French). The goals were to find a route to the East India Sea, and to mine the silver they found in the region. He was convinced that the Pacific Ocean was a mere two-week journey from Tidewater Virginia (Adams 2001). However, Arlington, who found this plan too politically risky, also 
denied this request. It was at this point that Berkeley became interested in contracting an independent expedition team to take on the challenge of exploring the Virginia mountains. He noticed that Abraham Wood and Edward Bland had recently made an expedition into the western Virginia Mountains. Because of Wood's prior experience and connections, Berkeley sought him to lead his expedition into that area. However, before Berkeley had contacted Wood, he instead contracted Lederer for the job. Lederer made a better choice than Bland and Wood for two main reasons. One, he was a German and not an Englishman. His nationality therefore posed no threat to any European power in North America at the time. Second, his interest in the land would be merely contractual, unlike Bland and Wood who had a conflict of interest. Lederer had shown no previous interest in settling, purchasing, or making a profit from land speculation in Virginia. However, Bland and Wood had already shown interest in land grants and land speculation in western Virginia. These facts made Lederer stand out above Bland and Wood, who were more likely to withhold information about valuable resources from the governor for the purpose of personal gain.

\section{Governor Berkeley's Leading Role}

Berkeley's choice in Lederer shows his foresight in planning the expansion of the colony. Because he was German and not English, Lederer was a good choice to lead an expedition into the western Virginia region. A loose political peace between the European powers in North America was susceptible to breaking at any point. By hiring Lederer to explore Virginia's mountainous western lands, Berkeley hoped to avoid an international political incident. A German could cross borders in North America that Englishmen could not. Germany had no large colony in the Americas, and no political 
hold. Therefore, Spain, France, and the Netherlands would not see a German as a threat to their land claims. If Lederer were captured or killed by any of these enemy states, then Virginia (and England) could claim they knew nothing about him. Lederer was an international buffer-his nationality afforded him the ability to travel between colonial powers in North America, and his contract with Berkeley gave him the authority to work within the colony of Virginia.

The contract between Lederer and Berkeley once existed as a written document. ${ }^{10}$ This is known because Lederer produced the document when confronted by Major Harris and his cronies during the second expedition. While this made sense (an existing written contract better ensured payment and passage through English territory), it raised an interesting question. If Lederer and Berkeley were trying to keep Lederer's affiliation with the English clandestine, then why was Lederer carrying the expedition contract with him? If the Spanish or the French had captured Lederer, they would have searched his person and discovered the contract. It must be that Lederer did not expect to encounter any of these people, or that he was being obtuse in his thinking. Having read Lederer's thoughts (through his journals), I am inclined to believe the former. Lederer knew exactly how far he could travel before encountering the Spanish or the French, and he traveled only as far as the knowledge of his Native American guides safely advised. ${ }^{11}$

\footnotetext{
${ }^{10}$ Berkeley's 1671 commission letter to Lederer still exists in current records. These records were combined into a text titled, Sir William Berkeley and the Forging of Colonial Virginia (2004) by Warren M. Billings.

${ }^{11}$ Berkeley believed (as many did at that time) that it was a mere two weeks from the Atlantic Ocean to the Pacific Ocean. Lederer, a well-informed explorer, knew better. Through his contacts with Native Americans and other explorers of the region, Lederer most likely knew that the expedition would never reach the Pacific Ocean in such a short amount of time. He stated as much in the epilogue to his journals. His goal, most probably, was to explore the region as much as possible, gather any information he could, and report back to Berkeley about his discoveries in the mountains (Alvord \& Bidgood 1912).
} 
Berkeley perhaps chose Lederer for the expedition into western Virginia because of his German nationality. However, being a German in Virginia later became an inconvenience. Lederer became a pawn in the war of political turmoil of the time. It was a matter of social politics, not international politics or his exploration skills that caused trouble for John Lederer. While his journals were as exact as any, he was an outsider--an outcast German in a land of the British--and no one in Virginia was going to take his word over an Englishman's. Lederer stated a much in the epilogue to his journals. The rumors about Lederer spread by Major Harris and others raised questions about the need for the expeditions. Eventually, Berkeley found himself attacked for spending the colony's taxes on "the German" (Cumming \& Rights 1958). Virginia was an English colony, and its colonial society did not welcome outsiders. In fact, many colonial citizens kept company only with other citizens of like nationality. When Major Harris (an English military companion on Lederer's second expedition) abandoned Lederer on his second journey, the wheel of fortune was set in motion against him. Harris, being English, was better connected socially and politically, and therefore was able to decry Lederer as a charlatan. Even Berkeley found it politically necessary to estrange himself from John Lederer. Other members of the Tidewater society no doubt found Lederer distasteful simply because of his ethnicity and because Lederer, a German, had dared to do what an Englishman could not.

Lederer, though he had guides and contacts in the Virginia frontier, was alone politically and a pariah in colonial Virginia (Drake 2001). ${ }^{12}$ He was not an independent

\footnotetext{
${ }^{12}$ Germans, like Lederer, came to the colony of Virginia, but (like other groups like the Scotch-Irish) kept to themselves (in a large part due to language and cultural barriers). This changed as the groups
} 
contractor of land. He was instead a "hired gun" paid to explore and document the land for the colony. He therefore served at the pleasure of Berkeley. Lederer never expressed an interest in owning or living on land in the region. He was simply an explorer, not a member of prospective landed gentry. ${ }^{13}$ However, his role as an expedition leader empowered Berkeley and Talbot with the knowledge and documentation necessary to procure public and political support for the colony of Virginia.

\section{The First Expedition: March 1669}

Lederer's first expedition set out in March 1669 (Alvord \& Bidgood 1912), when he and three Native American guides left from the York River in Virginia and set out for the summit of the Blue Ridge Mountains. This initial expedition showed evidence of what commodities the western mountains of Virginia held, and what dangers were to be faced. Lederer traveled due west from the head of Pemaeoncock (Pamunkey) River, also known as the York River, to the summit of the Blue Ridge of the Apalataean (Appalachian) Mountains. The first expedition's journal records Lederer's journey from the ninth of March until at least the twenty-fourth of March. After that date, there is no other mention of calendar time, and Lederer stated only that he returned back the way he came (Alvord \& Bidgood 1912). Lederer described the attack of a doe by a bobcat, the Native American history of the region, the discovery of mica, and his near-fatal encounter with quicksand. He also noted snakes in the lowlands and extremely cold temperatures in the higher elevations. All of these aspects showed what could be expected on an expedition into Virginia's western mountains. This expedition, as well as

intermarried later in history, but the two groups were at odds with each other during the early years of colonial settlement (Drake 36-38). 
the two following expeditions, produced evidence of innumerable commodities within the western mountains of Virginia.

In this first expedition, Lederer mentioned the names of his three Native American guides. They were Magtakunh, Hopottoguoh, and Naunnugh, and it was possible that they were members of the tribal village at Shickehamany (Chickahominy) near the falls of the York River where the expedition set out (Alvord \& Bidgood 1912). These Native American guides not only helped Lederer blaze a trail through the wilderness, but also hunted food and water for the expedition and offered explanations about the wildlife, plants, natural resources, and the various Native American tribes they met on the expedition. For example, on the first day of the first expedition, the group found a large rattlesnake measuring two and half yards long and "as big about as a man's arm" (Alvord \& Bidgood 1912). The group noticed a bulge in the snake's belly, and thought that it was a pregnant female snake. However, once they had killed the snake they found a dead (and half-digested) squirrel in the snake's stomach. Lederer wondered how a snake could catch a nimble animal like a squirrel, and his guides told him that the snake had charmed the squirrel out of the tree with its stare. However, Lederer stated (in his journal, not to his guides) that he believed the snakes attacked the squirrels in their nests instead (Alvord \& Bidgood 1912). This logical explanation was typical of Lederer, as was his diplomatic deference to his Native American guides. Even as early as this first expedition, it seemed that Lederer had a good prior knowledge of the Native American mind and social graces. His admiration of them was also apparent in his recording of their names in his journal. Other explorers and Europeans of the time typically would not

\footnotetext{
${ }^{13}$ This point lends Lederer more credibility. He is not trying to colonize his own land grant, and that is one
} 
have given any recognition to Native Americans, who they regarded as savages and inferiors.

The second day of the expedition brought the group to the marsh between the Pemaeoncock (Pamunkey) River and the River Matapeneugh. The group crossed the river over a peninsula where the north and south branches of the Pemaeoncock River form the Ackmick River. Lederer stated that between the two branches of the river was the grave of the Native American Chief Tottopottoma, who was killed while fighting for Virginia against the Ricahecrian tribe in 1656. The area was named Tottopottoma in honor of this Native American chief (Alvord \& Bidgood 1912).

On the far side of this river, Lederer's expedition again encountered wildlife. They witnessed a bobcat kill the doe, and subsequently the expedition members killed the bobcat. Lederer described the cat as a little larger than an English fox, of a reddish-gray color, and "fierce, ravenous, and cunning" in its hunting ability. These cats, he wrote, had difficulty in catching deer on foot because the deer were such fast runners. However, the wild cats caught the deer by perching in trees and pouncing upon them as they passed beneath the tree. Lederer reported that the wild cat's fur was not fine like a beaver or mink, but that it could still make warm clothing. He also said the cat's meat was "very rank like a dogs," but was "still eaten by the Indians" (Alvord \& Bidgood 1912). The scene portrayed resources of the Virginia frontier. The deer was a food source; the bobcat was a danger. In addition, Lederer mentions the fur of the bobcat, which was a possible commodity.

less reason to believe that he "fantasized" his expedition reports. 
Lederer found the Appalachian Mountains both beautiful and daunting. The terrain became a problem on the eleventh and twelfth of March 1669, and Lederer reported nothing in his journal except, "I found the ways very uneven and cumbred with bushes"(Alvord \& Bidgood 1912). This lack of writing was more likely the result of rough traveling conditions than from lack of observations. Many later expeditions into the Appalachian Mountains also found travel difficult. Evidence of challenging topography was commonplace in expedition journals into this region, and some would say the terrain is still a challenge in modern times.

Lederer's next journal entry came on the thirteenth of March, when he noted the mineral wealth of the region. He reported that the group crossed a very winding river four times on that day, and he discovered "isinglas" or mica in a great quantity. In addition to this, he found transparent crystals capable of cutting glass (but made no mention of what mineral they were). He reported also that he sent these mineral samples, along with white marchasite that he purchased from the Native Americans, to Berkeley (Alvord \& Bidgood 1912). ${ }^{14}$

On the following day, March 14th, Lederer described his first view of the Appalachian Mountains. He stated, "Their distance from me was so great, that I could hardly discern whether they were mountains or clouds, until my Indian fellow travellers prostrating themselves in adoration, howled out after a barbarous manner, 'Okee Paeze' meaning 'God is nigh"' (Alvord \& Bidgood 1912). That was the first of many observed religious beliefs and practices by Lederer of the Native Americans in the Appalachians. It is documented that the Native Americans saw the Appalachian Mountains as a region

\footnotetext{
${ }^{14} \mathrm{He}$ sent these to Governor Berkeley after returning to "civilized" Virginia (Alvord \& Bidgood 1912).
} 
inhabited by spirits, both good and evil, which they sought to supplicate (Cumming \& Rights 1958). On his other expeditions, Lederer also noted the religious beliefs and rituals of the various Native American tribes that he met.

Despite all his preparations, Lederer found his life in danger on the fifteenth of March when he was nearly swallowed by quicksand after crossing the south branch of the Rappahannock River. Later that day, he reported large herds of red and fallow deer (that he implied by the entry he had noticed before but had not mentioned. Lederer discussed these red and fallow deer at length in his third expedition journal). In addition, he observed there were bears in the forests. He also reported one of the most contested observations within his expedition journals. Lederer wrote that he had observed "small leopards" in this region. However, leopards are not indigenous to the Appalachian Mountains. He made the distinction, however, between these alleged leopards and the mountain lions. He claimed not to have seen any lions, although he noticed, "their skins are much worn by the Indians." However, if he had not seen a live mountain lion, how could he have made the proper distinction between it and a leopard? It is theorized that in translating the text from Latin into English, Talbot had made a mistake and called a "cougar" a "leopard" (Cumming \& Rights 113). Quite possibly the mountain lion and the "small leopard" were one and the same. Either way, this was evidence that there was a dangerous population of large cats in the region.

In addition to the lions, leopards, and bears, Lederer also observed a large number of wolves, which caused him much distress. The wolves came into the expedition's camp and howled nearby, but the Lederer and the guides built fires that kept the beasts at bay. In addition to wolves, Lederer reported beavers and otters in every river, and a large 
population of gray foxes lingering in the forests (Alvord \& Bidgood 1912). These reports showed that the Appalachian region was a source of abundant commodities and numerous dangers. Through his reports of dangers and commodities, Lederer not only revealed the monetary value of the land, but also the risks involved in settling the land and exploiting its natural resources.

On the seventeenth of March, Lederer's expedition reached the Blue Ridge of the "Apalataei" ${ }^{15}$ Mountains. At that point, he made the observation that the air was "very thick and chill". He also found a stream or mountain spring whose water had an "allumish taste"(Alvord \& Bidgood 1912, 148). ${ }^{16}$ While seeming unimportant, this entry accidentally shows evidence of coal in the region. Coal, when it is processed, gives off aluminum as a by-product. In addition, when water runs through coal deposits, it would pick up any minerals in it (Buckley 149). ${ }^{17}$ An "allumish" tasting spring in the region gave evidence that Lederer had traveled into the coal-producing region of the Appalachian Mountains. It was highly unlikely that Lederer knew what minerals were in the region prior to his explorations, and he never mentioned coal. However, by his referring to alum, he had inadvertently shown that he had explored the coal-rich Appalachians.

On the eighteenth of March, Lederer reported his ascent of the Apalataei (the Blue Ridge). He tried going up on horseback, but the incline was too steep. He left the horse with one of the Native American guides, and the other two guides accompanied him on his climb up the mountainside. He reported not only a steep ascent, but also

\footnotetext{
${ }^{15}$ The Appalachian Mountains.

${ }^{16}$ Allumish--like alum, a derivative of aluminum (Alvord \& Bidgood 1912).

${ }^{17}$ Buckley 2004.
} 
dense vegetation. Lederer wrote that the height of the mountain was overwhelming, and that it took him all day to reach the top. He stayed the night on top of the mountain, and in the morning saw, "a beautiful prospect of the Atlantick-Ocean washing the Virginia shore" to the east. However, the reciprocal view was even more astounding to Lederer. He saw nothing to the north and west except mountains larger than the one he had climbed the previous day, and that proved the end of his first expedition (Alvord \& Bidgood 1912, 148). This observation was enlightening as to Lederer's character. It is doubtful that he saw the Atlantic Ocean from the top of the Blue Ridge Mountains, but that is a minute point. The larger point was the expedition's goal in relation to this observation. The goal of Lederer's expedition was to find a route to the Pacific Ocean by crossing the Appalachian Mountains. If Lederer had been less scrupulous, he could have stated that he saw the Pacific Ocean in the distance to the west. However, he did not. He wrote that he saw the Atlantic Ocean in the east, and nothing but mountains to the west.

Lederer and the two Native American guides tried to find a path through the mountains until the twenty-fourth of March. Finally, the cold weather forced the end of the expedition. Lederer traveled in a vain attempt to find an easier route through the mountains, but decided to turn back down the mountain and rejoined his third Native American guide (Alvord \& Bidgood 1912). This initial expedition could have been deemed a failure because Lederer did not find a route to the East India Sea. However, the goal of the expeditions changed as more information was acquired about the region. It was apparent that there was much land available for speculation, in addition to the abundance of commodities and trade among the Native Americans. Therefore, the focus 
of Lederer's expeditions changed from finding a route to the East India Sea to discovering the wealth that was in the western mountains of Virginia.

\section{The Second Expedition: May 1670}

On this expedition, Lederer took his Native American guides and a British soldier, Major Harris (Alvord \& Bidgood 1912). ${ }^{18}$ This expedition occasioned the most scholarly debate of Lederer's journeys into the wilderness, and reveals how much of an outsider Lederer was in Virginia.

Lederer's second expedition set out on the twentieth of May 1670 from the Falls of Powhatan on the James River. On this expedition, Lederer took his Native American guides and a British soldier, Major Harris. They also brought along "five Indians" as guides and "twenty Christian horse" (Alvord \& Bidgood 1912, 149).

On the twentieth of May 1670, the second expedition traveled toward the village of the Monakin (also Manakins or Manacans). They reached the village on the twentysecond of May, and were shown "welcome" when the Monakins fired shots into the air. ${ }^{19}$ These Native Americans must have been on very good terms with the Virginians, because they possessed guns.

It was also there that an interesting cultural structure was observed. Lederer found a structure of stones piled into a pyramid shape. The priests of the tribe told Lederer that the number of stones in the pile was equal to the number of Monakin people who had emigrated from an overpopulated area to the area they were currently in. The

\footnotetext{
${ }^{18}$ Major Harris received his rank in December 1656 and was Abraham Wood's subordinate in the Charles City County regiment (Alvord \& Bidgood 1912).

${ }^{19}$ The fact that the Monakins had guns reveals that they were on extremely friendly terms with the British. It was, in fact, illegal to sell arms and ammunition to any Native American, but these must have been an exceptional case (Alvord \& Bidgood 1912).
} 
man who led the group from the overpopulated region was named Monack, and thus the tribe called themselves the Monakin (Alvord \& Bidgood 1912). One cannot fail to compare the Monakins and the Europeans. The Monakins moved their surplus people into another uncolonized area, much the same as Europeans did with North America (Sweet 2003). This naming of the tribe for the original leader is also notable, and further in Lederer's expedition journals the Native American tribes are similarly named either for the region or town they inhabit (such as the Sara). Descriptions of the "priests" of the tribe (presumably the elders who held many occupations in the village such as physicians, storytellers, and religious figures) were found throughout Lederer's expedition journals, although their political power and religious practices vary considerably.

While at the Monakin village, Lederer consulted the village's "ancient man" and asked him the best route to the mountains. This action did two things. First, it proved that Lederer respected the Native Americans' knowledge. Secondly, it more than likely endeared him to the Monakin, since they would have noted this respect. The "ancient" Monakin man used his staff and marked two paths on the ground. One way led through the Mahock tribe's lands, and the other led to the Nahyssans tribe's territory. Lederer planned to take one of the Native American trails. However, there was dissension in the ranks concerning the route they were to take. While Lederer was willing to follow the Native American's advised course, the Englishmen gave no heed to the old man's directions and instead insisted on traveling "by the compass due west" (Alvord \& Bidgood 1912, 149). The expedition party's ignorance of the terrain's impact and their prejudice against the Native Americans doomed the expedition to collapse. Lederer had 
no way of knowing how bad the terrain directly west was, and so he diplomatically deferred to his military counterpart.

Lederer reported being very disappointed at traveling in a straight line over the land, and described it "as it does with those land-crabs, that crawling backwards in a direct line, avoid not the trees that stand in their way, but climbing over their very tops, come down again on the other side, and so after a days labour gain not above two foot of ground"(Alvord \& Bidgood 1912, 149-50). For nine days the expedition traveled over rough ground that made the horses lame. In addition, the mountain had no food or water on it to supply the expedition--Lederer reported the land was devoid of "both grain and herbage" (Alvord \& Bidgood 1912, 150). However the expedition continued on, and the explorers hoped for better luck.

The expedition crossed this large and barren mountain, and finally reached the south branch of the James River on June third. It was there that Major Harris (in his ignorance) declared a great discovery. Harris discovered that the river ran north, and took that to mean the river was an "arm of the lake of Canada." Demonstrating his wry sense of humor, Lederer stated that Harris was so "transported with this fancy, that he would have raised a pillar to the discovery" (Alvord \& Bidgood 1912, 150). Harris may have been a military man, but his usefulness in the wilderness of western Virginia was hampered by his lack of experience in the region. His rather comical "discovery" gave evidence that although he was an Englishman in an English colony, he was not the most informed about his surroundings. Understandably, Lederer ignored Harris's ramblings, and pressed the expedition across the river. At this point, the other members of the expedition began a violent protest, and Lederer only appeased them by showing the 
actual contract between himself and Berkeley. Lederer wrote, "the rest of the company were so weary of the enterprise, that crying out, one and all, they had offered violence to me, had I not been provided with a private commission from the Governour of Virginia to proceed, though the rest of the company should abandon me; the sight of which laid their fury" (Alvord \& Bidgood 1912, 150). Lederer was the leader of the expedition--and according to Berkeley's orders the most important member of it. He was given written permission by Berkeley to continue his expedition even if he had to go alone.

At this, the British cohort of the expedition became very angry with Lederer. They saw Lederer as an uninformed German, and Harris used that to his advantage. Harris, a member of the English majority, was allotted more social power than Lederer. Lederer's private commission papers from Berkeley proved he was the senior official on the expedition, but Harris and the other expedition member still deserted him. Harris, the ringleader in the mutiny, was unwilling to follow Lederer's commands. Obviously uneducated on the terrain, necessary provisions, and culture of the Native Americans, Harris found himself humiliated by his own ignorance, and in unknown territory. He appealed to the other men's prejudices toward Germans and Native Americans to belittle Lederer's decisions, and used his social status as a British citizen to create dissension in the ranks. Upon his return to Tidewater Virginia, Lederer found himself called a charlatan by the Virginians, and the malice against him was so great that even Berkeley found it politically necessary to distance himself from him (Alvord \& Bidgood 1912). Lederer proceeded on with the expedition despite the complaints of the other expedition members. Near the river, Lederer described the lesser hills, or "Akontshuck," that were impassable. The rocks, he stated, resembled "eggs set up on their ends." The 
breadth and topography of the rocky riverbed made it impassable. The riverside was strewn with "straws and rotten chunks." These were also in the trees some twenty-two feet above the water, and Lederer explained the spring floods had put it there (Alvord \& Bidgood 1912, 150). This observation showed a danger of living in the mountains of Virginia. Flooding--especially flash flooding--was a great danger there.

\section{June 5, 1670: The Schism}

On the fifth of June 1670 the expedition separated, and Lederer had one last laugh. Previously, the Englishmen had scoffed at Lederer's choice of provisions. While the rest of the men brought white biscuits, Lederer chose to bring parched "Indian meal" (cornmeal) bread. The white biscuits molded over, but Lederer's parched meal did not. Lederer was obviously hurt by their mutiny, and did not share this bounty with the others when they abandoned him by setting off for Appomattox (Alvord \& Bidgood 1912, 151). Following this episode in his journals, Lederer's descriptions of the second expedition's events become problematic for some scholars.

Following the mutiny, Lederer continued southward (from the Mahock village into what eventually became North Carolina) with only one remaining member of his party, a Sasquesanhanough Native American named Jackzetavon. Lederer also changed his course, favoring the route previously recommended by the ancient Monakin man. On Sunday, the fifth of June, Lederer and Jackzetavon traveled out of the barren land through "difficult ways, without seeing any town or Indian" (Alvord \& Bidgood 1912, 152). On the ninth of June they reached Sapon, the village of the Nahyssans. This was one of the tribes whose land the "ancient man" of the Mahock had suggested the expedition pass through. Lederer had traveled almost one hundred miles from the 
Mahock village to Sapon which was located on the Shawan River (Cumming \& Rights $1958) .^{20}$

The town of Sapon was built on a hill that was surrounded by a river. Initially, the Saponys were uncomfortable with Lederer's visit. They had been at war with Virginia for ten years. Lederer must therefore have been a brave man to visit this tribe. However, Lederer knew their ways, and allowed himself to be strictly observed by the Sapony people. He also gave them "trifles of metal and glass" as gifts. Following these gestures of goodwill, Lederer was welcomed "with all imaginable demonstrations of kindness" and with many honors, including a sacrifice (he didn't say of what sort), and a proposal that he marry "some of their great mens daughters." Lederer turned down this generous offer, but did accept passage through their land and promised to visit them in six months (Alvord \& Bidgood 1912, 152). Lederer's rapport with the Native Americans made it possible for him to travel unmolested through their territory. It is doubtful that Harris, with his prejudice against Native American society and his overweening English pretension, could have done the same. Lederer's good relationship with the Sapony tribe continued beyond Lederer's time with them. When a later expedition of Thomas Batts and Robert Fallam came to their village, the tribe (that had previously been hostile to Virginians) greeted them amicably (Cumming \& Rights 1958).

In addition to free passage, Lederer was also given information about the region, including other villages and landmarks. For example, the Saponys informed Lederer of

\footnotetext{
${ }^{20}$ Staunton River in Campbell County, Virginia (Cumming 1958).
} 
their chief's, or "kings" residence that was located on the river. This residence was called pintahae (Alvord \& Bidgood 1912, 153). ${ }^{21}$

After leaving Sapony, Lederer traveled to Akenatzy, which was an island in the Sapony River located fifty miles from the Sapon Village. The country was high and level, and had a rich soil with many old growth trees. The Native Americans were healthy and vigorous because of their living in this idyllic climate. The river had a very strong current, and that created a natural defensive barrier around the village (Alvord \& Bidgood 1912).

Two "kings," or chiefs, led the social order of the Akenatzy. One king was "presiding in arms" for the defense of the tribe, and the other was the overseer of hunting and husbandry. Everything (food, shelter, etc) was communal, with the exception of the wives. On the north shore of the island the people grew crops, and they stored a year's supply of food in case of a siege by another tribe. The distribution of the food was communal as well. Each tribesman in his turn would feed the entire group, and one of that man's honors would be a seat between the two kings at the feast (Alvord \& Bidgood 1912). This complex social order signified a stable government within the Akenatzy people. Their society was possibly a result of friendly relationships with other tribes of the region and the productivity of their cropland.

In addition, the Akenatzy tribe's land may have been a governmental, cultural, and/or religious center for other tribes. For example, upon Lederer's arrival at Akenatzy,

\footnotetext{
${ }^{21}$ Lederer did not venture to pintahae, and this is more evidence that he was telling the truth. This Sapony "palace" was described in detail in the journals of Hernando De Soto. However, Lederer stated that he did not visit the place. If in fact Lederer had read and plagiarized De Soto's account of his expedition, then he would have certainly included a mention of this most fantastical building said to have been strung with layers of pearls and other precious items. However, Lederer did not mention this place. He described the
} 
he met "four stranger-Indians whose bodies were painted in various colours with figures of animals whose likeness I had never seen." These Native Americans were said to be from a distant western land, and told Lederer that "they were the only survivors of fifty, who set out together in company from some great island ... to the northwest; for I understood that they crossed a great water, in which most of their party perished by tempest, the rest dying in the marishes (marshes) and mountains by famine and hard weather, after a two-months travel by land and water in quest of this island of Akenatzy" (Alvord \& Bidgood 1912). Lederer believed that those four visiting Native Americans were from a tribe near the island of New Albion or California, and then stated that it was possible that the four had traveled "a great arm of the Indian Ocean or bay" into the North American continent towards the Appalachian Mountains. The theory about an arm of the East Asia Sea extending inland toward the Appalachian Mountains is one that Lederer strongly adhered to throughout his expedition journals. The ability of this Native American community to attract other tribes to visit the land is interesting. It showed that the Akenatzy were possibly the parent tribe of other regional tribes, or that they were a powerful nation with influence over other tribes in the area.

During the following day a Rickohockan ambassador was received with his retinue and there was a great celebration. The Rickohockan ambassador and his group had painted themselves with auripigmentum. ${ }^{22}$ Auripigmentum is also known as orpiment. According to Encyclopedia Britannica (2005), it was a source of yellow dye

smaller "temples" and "oratories" that were filled with a great store of pearls that the natives had won in battle (or had probably been given as tribute) by the tribes in Florida (Alvord \& Bidgood 1958).

${ }^{22}$ Arsenic sulfide, also known as orpiment. It is a mineral that produces yellow dye and paint. It is also highly toxic. 
and paint during the eighteenth century. This mineral would certainly have been a valuable commodity at the time.

In addition, Lederer had a theory that the Rickohockans (a group belonging to the Cherokee) lived on the shores of a great ocean, and he sought to prove this theory. They were stated to have lived "not far to the westward of the Apalatean mountains, [and] are seated upon a land, as they term it, of great waves." Unbeknownst to Lederer, the Rickohockans actually lived on the shores of Lake Erie (Alvord \& Bidgood 1912, 155).

There was little time for Lederer to investigate his theory, however. During the welcoming celebration, Lederer stated that the room filled with smoke and the Akenatzys murdered the Rickohockan ambassador and his entourage. During the fray, Lederer and his guide escaped without finding out the source of the auripigmentum or the location of the Rickohockan homeland (Alvord \& Bidgood 1912). Fearing for his life and completely horrified by the actions of the Akenatzy, Lederer left their land and headed south-southwest.

Lederer and his guide continued to follow a Native American trail through the region, traveling from the fourteenth until the sixteenth of June. He stated that they traveled "sometimes by a beaten path, and sometimes over hills and rocks". Thirty miles later, they reached the Oenock village (Alvord \& Bidgood 1912, 156).

Lederer described the Oenock as a hard-working people. He stated, "the country here, by the industry of these Indians, is very open and clear of wood. Their town is built round a field" (Alvord \& Bidgood 1912, 156). This tribe was very athletic, and in this field they exercised "with much labour and violence, and in so great numbers, that I have seen the ground wet with the sweat that dropped from their bodies: their chief recreation 
is slinging of stones" (Alvord \& Bidgood 1912, 156). This could have been a reference to a game similar to lacrosse. This exercise may seem maddening, but it had a place in their culture. Lederer observed, "They are of mean stature and courage, covetous and thievish, industrious to earn a peny (penny); and therefore hire themselves out to their neighbours, who employ them as carryers (carriers) or porters." In addition to this amazing work ethic, they planted an abundance of grain, planted three crops in a summer, and out of their granary supplied all the adjacent area (Alvord \& Bidgood 1912, 156). The Oenock differed from other tribes in their style of architecture, and Lederer attributed it to their living in the mountains. He stated, "These and the mountain Indians build not their homes of bark, but of watling and plaister (plaster). In summer, the heat . . . makes them chuse (choose) to lie abroad in the night under thin arbours of wild palm. Some houses they have of reed and bark; they build them generally round" (Alvord \& Bidgood 1912, 157). Their meals are cooked in an outdoor oven, where they "lay up their corn and mast" as well as parch nuts and acorns. Baking the acorns removed the "rank" oiliness of the acorns and produced "amber colored oil," and the baked nuts produced "milky liquor." The Oenock then mixed the nut and acorns oils together and dipped "cakes" into it. It was considered a delicacy (Alvord \& Bidgood 1912, 157).

After leaving the Oenock town, Lederer passed through the land of the Shanocky tribe. They lived "upon a rich soyl (soil) and ... abounded in antimony"(Alvord \& Bidgood 1912, 157). ${ }^{23}$ Antimony, according to Encyclopedia Britannica (2005), was used in the treatment of medical conditions such as fever. Lederer observed that this tribe was very similar in customs and social order to the Oenock, and did not stay long

\footnotetext{
${ }^{23}$ Antimony is also known as boneset (Alvord \& Bidgood 1921).
} 
with them. He traveled further west-southwest until the nineteenth of June. After that, he traveled two more days through "troublesome" lands filled with marshes and thickets before reaching Watary (presumably the land of the Watary tribe) that was located forty miles from the Oenock. He mentioned reaching the Watary town of Shakor.

The Watary Native American tribe's culture was so distressing to Lederer that he made a clear distinction between it and the other Native American governments that he encountered. It is the only tribe Lederer met where the citizens were slaves to their "king." Lederer observed that the "king" was hospitable to strangers, but was very "superstitious" in his religious beliefs. For example, the tribe's "king" had three young men to go and kill as many young women of their enemies' tribes as they could. The souls of these slain women were believed to become servants in the afterlife to the "king's" recently deceased son. The three young men returned with the "skins torn off the heads and faces of three young girls, which they presented to his majestie, and were by him gratefully received." This horrific action caused Lederer to depart from the Watary and he headed west on the 21st of June (Alvord \& Bidgood 1912, 158).

He kept his western course for over thirty miles. It led him to Sara, a town in the Cherokee mountains of present-day North Carolina. The mountains, according to Lederer, became easier to travel at this point because they leveled out and decreased in elevation. He mentioned that the Spaniards had previously named this part of the Appalachian Mountains Suala (translated as "its wing") (Alvord \& Bidgood 1912, 158). 
The Spanish name for the region shows that the town was on the "border" between the English and Spanish territories in North America (Cumming \& Rights 1958, 82). ${ }^{24}$

Commodities that Lederer found in the suala of the mountains included cinnabar, which was the source of a deep purplish red color dye. Lederer noted that the Native Americans used it for coloring their faces. Also, Lederer discovered small salt cakes among the Sara tribe. It was possible that the Native Americans had obtained that salt from the sea, but Lederer stated that he believed they got them out of salt licks. He did not observe this action, but based this theory on the tribe's distance from the ocean. Lederer also stated that other unnamed minerals existed in abundance in the region, but he did not mention which minerals. It must have distressed him that he could not discern where the salt came from, but he stated that he did not want to imply there was rich mineral wealth, even when it was possible (Alvord \& Bidgood 1912). Lederer maintained a conservative stance in regard to the probable wealth in the western mountains of Virginia. The commodities of this region did not receive a significant mention in the expedition journals, but that may be because of its location so close to Spanish territory.

The society at Sara functioned based on an interesting dynamic. Lederer had observed that the Native American social structure at Sara was centered on the whims of the town's children. He also noted that the tribe did not ever "chastise" their children "for any mischief or insolence" (Alvord \& Bidgood 1912, 159). He found this rather perplexing because a little Native American boy (angry with Lederer's not allowing the

\footnotetext{
${ }^{24}$ In fact, the Spanish had functioning missions to the southwest of the village. They were located inland from the Gulf of Mexico, and are mentioned in contemporary documents of the time (Cumming and Rights 1958).
} 
boy to shoot his horse) would have shot him with an arrow if Lederer had not appeased him with gifts. Still, the action "caused such a mutiny amongst the youth of the town, that the seniors taking my horse and self into protection, had much ado (and that by intreaties and prayers, not commands) to appease them" (Alvord \& Bidgood 1912, 159). Lederer did not conjecture why the youth of the tribe had so much power.

Traveling quickly, Lederer left Sara after that incident and traveled southsouthwest until the twenty-fifth of June. He reached Wisacky, near the lake that Lederer called "Ushery." This part of the journey was the most difficult for Lederer because the Ushery region was a large marsh filled with giant reeds that had left behind rock-hard stumps. He claimed that he led his horse through the marsh most of the way, and was surprised that he was not lamed by the knotty reed stumps or sucked down into a bog (Alvord \& Bidgood 1912, 159). Lederer stated, Lake Ushery's water "seemed to my taste a little brackish; which I rather impute to some mineral waters which flow into it, than to any saltness it can take from the sea, which we may reasonable suppose is a great way from it" (Alvord \& Bidgood 1912, 160). This comment foreshadows Lederer's later claim that the South China Sea was not accessible quickly by crossing the North American continent. He observed that the lake had, "many pleasant rivulets fall into it, and it is stored with great plenty of excellent fish" (Alvord \& Bidgood 1912, 160). Although there is no mention of specific size or type of fish, it is still an example of how Lederer showed the types of commodities available in the region. The reason for his exemption of the types of fish was because of a lack of information. Lederer did not observe fish being caught by the Ushery people during his stay, but he could have been told by the Ushery that the lake was full of fish without actually seeing them. 
Lake Ushery was described as having brackish water caused by nearby mineral deposits rather than it being close to an ocean or sea. Lederer included this information (it can be assumed) so as to not provoke his benefactors to think that he might have discovered an inlet from the sea. Lederer describes the Lake of Ushery as being about "ten leagues broad; for were not the other shore very high, it could not be discerned from Ushery. How far this lake tends westerly, or where it ends, I could neither learn nor guess" (Alvord \& Bidgood 1912, 160-1). Lederer made sure that all his points were covered. He mentioned that the water was brackish, but that was probably because of nearby mineral deposits. He stated that the lake was large, but the Native Americans did not tell him nor could he guess the size and distance of the lake. This explanation of the region had allowed Lederer to claim that Ushery was a lake, but still left room for error in case it proved to later be an arm of the sea. In fact, Lake Ushery was a geographic anomaly because no one knows exactly what it was. It may have been a large swamp, but it was certainly not a large lake.

Within this marshy region called Ushery dwelled a tribe of Native Americans (the Catawba) that were subject to a king (Cumming \& Rights 1958). The king presided over the Ushery Lake, Wisacky marsh, and all the land that was contained within a great ring of mountains that surrounded it. Lederer did not go into much detail about the land; he only stated that the entire place was called, "Ushery." Lederer possibly did not venture far into the region due to its rough terrain and dangerous marshes. On the twenty-sixth of June, Lederer noted a freshwater river. He distinctly stated that it was a freshwater river, and not salty or brackish. By mentioning it Lederer gave more information concerning the resources near the Ushery town. 
The town of the Ushery was more populated than any other in Lederer's travels, he claimed. The "king" did not live in the town, but instead lived somewhere three miles beyond its limits, and Lederer did not have the honor of meeting him during his stay with the Ushery (Alvord \& Bidgood 1912, 159). However, this tribe was not the only one in the vicinity.

The Ushery tribe was constantly on guard against the Oustack tribe that was living on the opposite side of Ushery Lake. The Oustack were a very war-like society, and Lederer was told they were "addicted to arms" (Alvord \& Bidgood 1912, 160). The art of war so enthralled the Oustack that even the women would fight in battle by "shooting arrows over their husbands shoulders, who shield them with leathern targets." The Oustack men were said to fight with silver hatchets, as one Ushery citizen stated that the hatchets were made of the same metal as the silver pommel of Lederer's sword. The Oustack would attack the Ushery in dugout boats and carry away people to be sacrificed to their idols (Alvord \& Bidgood 1912, 160). Whether these battles and kidnappings actually occurred is conjecture--this is a story told to Lederer by a member of the Ushery tribe, and should be treated as second-hand information. Lederer did not actually observe a battle between the Oustack and the Ushery, or the kidnapping of the Ushery citizenry by them. Within this simple explanation, Lederer has mentioned both a suspected commodity (silver) and a danger (the Oustack) within the region.

Lederer also made note of the wealth of the Native Americans. He stated that the Ushery women wore many feathered ornaments, and thought more highly of the peacock than any other bird due to its beautiful plumage. It was also very rare bird for that region. The tribes' people, stated Lederer, were more handsome than others he had encountered, 
and had "more civility to their carriage" than he had observed among the other Native American nations. In comparison to the Oustack, who were very war-like and domineering, Lederer concluded that the Ushery were very effeminate and somewhat lazy (Alvord \& Bidgood 1912, 160). It is noteworthy that Lederer compares two distinctly different tribes here. One of which is based upon a bit of second-hand information about the Oustack that was given to him by a member of the Ushery tribe. It seems that the women were the point on which the observation pivoted. Lederer claimed that the Oustack were war-like and vicious due to the female warriors, and the Ushery tribe was lazy and effeminate because they wore feathers and had civilized manners.

Whether or not they were effeminate certainly had no bearing on their religious faith. According to Lederer, the Ushery caused him great horror when he observed, "one of them (the Ushery) wrythe his neck all on one side, foam at the mouth, stand bare-foot upon burning coals for near an hour, and then recovering his senses, leap out of the fire without hurt or signe of any" (Alvord \& Bidgood 1912, 160). This showed that the Ushery had some sort of religious leanings, however grotesque they were.

This was one of the last mentions of the Ushery. Following this show, Lederer moved through the area in the same south-southwest direction as before. He learned from the Ushery, as well as from the Sara Natives who had come to trade with them, that two and a half days further south-southwest there was, "a powerful nation of bearded men" (Alvord \& Bidgood 1912, 161) which Lederer took to be the Spanish, as the Native Americans never had beards. Lederer had observed that the Native Americans had from their youth plucked out their facial hair. In addition to this information, he also learned that directly westward was a "government inhospitable to strangers" that was given no 
name, and over the Suala Mountains to the north lived the Rickohockans (Alvord \& Bidgood 1912, 161). This information was the turning point in Lederer's second journey. He did not think it was safe to venture among the Spaniards (though he was not English), because he may have been captured as a spy, imprisoned, or forced into labor in the Spanish mines. Therefore, he turned around on the twenty-eighth of June and began a journey back towards Virginia (Alvord \& Bidgood 1912).

In order to avoid the treacherous Wisacky marsh, Lederer traveled northeast, and he and Jackzetavon stumbled into a drought-stricken region that Lederer likened to a "barren sandy desert." The two men and the horses traveled through a land that "suffered miserably for want of water." Lederer stated, "the heat of the summer had drunk all the springs dry, and left no signe of any, but the gravelly chanels in which they run; so that if now and then I had not found a standing pool, which provident nature set round with shady oaks, to defend it from the ardour of the sun, my Indian companion, horse, and self had certainly perished with thirst" (Alvord \& Bidgood 1912, 161). No relief came to them until the twelfth of July when the group found the Eruco River. After crossing the river twice, Lederer and his companion came to the town of Katearas, which was a center of "great Indian trade and commerce, and chief seat of the haughty Emperour of the Toskiroro's [Tuscaroras], called Kaskufara, vulgarly Kaskous" (Alvord \& Bidgood 1912, 162). The Toskiroro "Emperor" Kaskufara was "the most proud imperious barbarian" Lederer claimed to have met on his second journey. The Toskiroro tribe was a complex, wealthy society and was aggressively greedy.

The "Emperor" Kaskufara demanded Lederer's gun and shot, and Lederer gave it to him in order "to ransom my self out of his clutches" (Alvord \& Bidgood 1912, 162). 
Lederer found that the Toskiroro people were preparing for "some extraordinary solemnity: for the men and the women of better sort had decked themselves very fine with pieces of copper in their hair and ears, and about their arms and neck, which upon festival occasions they use as an extraordinary bravery: by which it should seem this country is not without rich mines of copper"(Alvord \& Bidgood 1912, 162). Although Lederer made this assumption, he made no inquiries about the source of the copper wealth of the Toskiroros. He feared that the "Emperor" Kaskous would become suddenly provoked and act upon his "bloudy" (bloody) nature (Alvord \& Bidgood 1912, 162). It is notable that the most war-like and inhospitable tribes were the ones who allegedly had large stores of precious metals. Here, the Toskiroros had large abundances of copper, while the Oustack were said to have had silver. The tribes with the most valuable commodities for the European market are also the most dangerous to the Europeans. In a way, this warlike stereotyping dehumanized them, and made many Native American tribes vulnerable to extermination by the English. By making this observation, Lederer exhibited to Virginia the information necessary to conquer the wilderness and its people.

Beating a hasty exit out of Katearas, Lederer traveled through the forest until the sixteenth of July when he came to Kawitziokan, a Native American town on the banks of the Korenoke River. Without stopping, Lederer passed through the town and went on to Menchaerinck where he camped in the forest on the night of the seventeenth. On the eighteenth of July, Lederer traveled through Natoway to Apamatuck (Appomattox), Virginia (Alvord \& Bidgood 1912). The lack of any detail in these final days probably reflects the fact that these areas were well known to Europeans already. 
The most complex societies in the western Virginia mountains were the ones that held great wealth in commodities (metals, furs, grain), had complex social orders, that had trade markets and communications with other tribes, and those that had some form of religious order. These tribes - the Toskiroros, the Akenatzy, the Sapony, the Oustack, etc. - were all great threats to the settlement of the frontier. By reporting on them in his expedition journals, Lederer sought to inform Berkeley about the Native Americans of the region and which ones were the greatest dangers to future land speculation.

The final lines of this second journey state, "I reached that evening Apamatuck in Virginia, where I was not a little overjoyed to see Christian faces again" (Alvord \& Bidgood 1912, 163). When he reached Appomattox, the second expedition was over. Lederer's second expedition journal ended here, but scholarly debate about his second expedition continues to this day.

\section{The Third Expedition: August 1670}

Lederer's third and final expedition in August of 1670 was far less expansive and included less detail. Although it contained very little information and very few details, it was still notable because it contained Lederer's opinions and personal thoughts on the western Virginia mountains. Lederer's epilogues contained theories and analysis of the information that he thought would be useful to future expeditions and settlements in the western Virginia region. These epilogues contained conjectures about the lands beyond the Appalachian Mountains, gave instructions to those interested into the wilderness of North America, and gave advice to those wanting to trade with the interior's many Native American tribes. 
Talbot and Lederer likely made these additions in 1672, when Lederer's original three expedition journals were translated into English from Latin. These epilogues are records of the theories Lederer had about the region. He knew the region, and he also knew that the contemporary ideas about it were somewhat false. The possibilities for wealth within the Appalachians were limitless, but the land was much more rugged and vaster than previously thought. It would be several generations before anyone realized the extent of the continent and its commodities.

On August 20,1670, Lederer began his third and final expedition into the Appalachian Mountains in the western part of Virginia. This expedition started at the falls of the Rappahannock River in Virginia and traveled west to the Appalachian Mountains. On this expedition, Colonel Catlet of Virginia accompanied Lederer, and they took nine "English" horses and five "Indians" with them (Alvord \& Bidgood 1912, 163). The expedition began at the home of Robert Talifer on the 20th of August 1670, and that night they reached the falls of the Rappahannock River (which the Native Americans called Mantapeuck). After spending the night there, the group continued on across the river "where it divides into two branches north and south, keeping the main branch north of us" (Alvord \& Bidgood 1912, 163). The group traveled along the river at least until the twenty-third of August, where the shallow river barely got the horse's hooves wet (Alvord \& Bidgood 1912). ${ }^{25}$

On the twenty-fourth of August, the expedition traveled over a great plain that was filled with large herds of red and fallow deer. This may seem like a romantic sylvan

\footnotetext{
${ }^{25}$ This mention of low water levels hearkens back to Lederer's earlier mention of there being dry weather in the region during the summer of 1670 . This entry, though seemingly insignificant, may be evidence that Lederer did in fact travel through the regions he claimed to have traveled (Alvord \& Bidgood 1912).
} 
picture, but to Berkeley it was a ready and abundant food source for travelers and settlers of the area. At this point, Lederer begins an almost poetic account, reporting the changing seasons, water sources, and the American elk. These writings are a departure from the scientific observations evident in Lederer's two preceding journals. For example, Lederer explains the great plain and how it gave way to the foothills of the western Virginia mountains, but before the expedition went further Lederer wrote this account of the region:

These Savanae are low grounds at the foot of the Apalateans, which all the winter, spring, and part of the summer, lie under snow or water, when the snow is dissolved, which falls down from the mountains commonly about the beginning of June; and then their verdure is wonderful pleasant to the eye, especially of such as having travelled through the shade of the vast forest, come out of the melacholy darkness of a sudden, into a clear and open skie. To heighten the beauty of these parts, the first springs of most of those great rivers which run into the Atlantick ocean, or Cheseapeack bay, do here break out, and in various branches interlace the flowry meads, whose luxurious herbage invites numerous herds of red deer (for their unusual largeness improperly termed elks by ignorant people) to feed. (Alvord \& Bidgood 1912, 163-4)

This romantic vision of the plains makes it seem like a settler's paradise. It is quite obvious that Lederer did not observe this land in the seasons he describes (his three expeditions were all during the summer months), so therefore it is secondhand information given to him by either another expedition member or a Native American guide. The romantic spin and explanation of commodities is done for the sheer delight of those who wish to sell land in, or settle in the Valley of Virginia.

Lederer explained the "red deer" further in this same entry. He stated,

The right elk, though very common in New Scotland, Canada, and those northern parts, is never seen on this side of the continent: for that which the Virginians call elks, does not at all differ from the red deer of Europe, but in his dimensions, which are far greater: but yet the elk in bigness does as far exceed them: their heads, or horns, are not very different; but the 
neck of the elk is so short, that it hardly separates the head from the shoulders; which is the reason that they cannot feed upon level ground but by falling on their knees, though their heads be a yard long: therefore they commonly either brouse upon trees, or standing up to the belly in ponds or rivers feed upon the banks: their cingles or tails are hardly three inches long. I have been told by a New-England gentleman, that the lips and nostrils of this creature is the most delicious meat he ever tasted. As the red deer we here treat of, I cannot difference the taste of their flesh from those in Europe. (Alvord \& Bidgood 1912, 164)

This long-winded and somewhat faulty account of the "red deer" (the American elk) in Virginia and its attributes was a further appeal to those planning to settle in the region. Lederer realized that his expedition journals had to include one fundamental thing--a detailed description of the commodities available to prospective settlers, and it helped to stress the similarities of these commodities to what European settlers had left behind in Europe. This explanation of the American elk is by far the best example of that to be found in Lederer's journals.

After leaving the savannah and the herd of elk behind, the expedition traveled to the Appalachian Mountains on the twenty-sixth of August. The expedition could find no easy path up the mountain, so two or three Native Americans stayed behind with the horses while the others ascended. The process of climbing the mountain was not easy. Lederer wrote, "The ascent was so steep, the cold so intense, and we so tired, that having with much ado [we] gained the top of one of the highest [mountains]." Of course these hardships did not keep the men from claiming the land in the name of the King of England, naming the mountain after him, and drinking brandy in his honor (Alvord \& Bidgood 1912, 165). It was notable that Lederer included this in his expedition journal, as the naming of the mountain for the King of England might induce his majesty to be 
more generous to Lederer's benefactor. In addition, it made the region more appealing to British patriots.

The naming of the mountain for the King of England had two distinct political purposes. One was that Lederer had shown deference to the King and thus hoped to receive his (and his loyal subjects') favor, and the second gave the English a political stake in the wilderness that was yet unclaimed by any other European nation. However, Lederer still did his job -- he informed his readers about the hardships (steep land, cold temperatures) and the commodities available (elk, water) in the area. In addition, Lederer mentions another mountain, higher than the one they were currently on, that Catlett had estimated to be no "less than fifty leagues away" (Alvord \& Bidgood 1912, 165). The topography again was a huge roadblock to the third expedition. However, it was evident in this account that Lederer was able to travel further into the mountains when he was not burdened with English soldiers or gentry.

In addition to the topographical challenges, Lederer mentioned a specific danger that he experienced personally. On the night of the twenty-sixth of August, he was bitten on the end of his finger by a "mountain spider" while he slept. He stated that if one of the Native American guides had not sucked out the poison, he would have died from the bite. The type of spider was unknown, but Lederer discussed the occurrence at length. He stated, "the venome shot up immediately into my shoulder, and so inflamed my side, that it is not possible to express my torment" (Alvord \& Bidgood 1912). Lederer called the Native American who administered the antidote a "physician." This showed that he held a feeling of collegial respect for any individual who had knowledge in medicine. Lederer had tremendous respect for Native American way of life and their ability to use the 
natural environment to assist them. For example, the Native American antidote for the spider bite included:

a small dose of snake-root powder, which I (Lederer) took in a little powder: and then making a kinde of plaister (plaster) of the same, applied it neer to the part affected: when he (the Native American physician) had done so, he swallowed some by way of antidote himself, and suckt my fingers end so violently, that I felt the venome retire back from my side into my shoulder, and from thence down my arm: having thus suckt half a score times, and spit as often, I was eased of all my pain, and perfectly recovered. (Alvord \& Bidgood 1912, 164)

On the following morning, the group continued with a perfectly recovered Lederer. Lederer had thought that a rattlesnake had bitten him. However, one of the Native American guides showed him the wound, described the effects of the poison, and determined that it had been a spider. Later in that day, the Native American guide showed Lederer the type of spider that had bitten him. It was described as, "not unlike our (European) great blue spider, onely it is somewhat longer. I (Lederer) suppose the nature of his poison to be much like that of the tarantula" (Alvord \& Bidgood 1912, 165). This event showed how much Lederer and his guides depended upon one another. Lederer was not only their leader, but he was also their friend. He respected their knowledge of the land and the animals, and was anxious to learn about the medical practices of the Native Americans. Following Lederer's recovery from the spider bite, the expedition decided to turn back. The decision was unanimous for they saw no probable passage through the mountains. Lederer stated that they made no further discoveries on that expedition, and there the third expedition journal ended (Alvord \& Bidgood 1912, 166).

Though the expedition ended there, Lederer was not finished analyzing his discoveries. A well-educated man, Lederer made conjectures about the land beyond the 
western Virginia mountains, gave instructions to those interested into the wilderness of North America, and suggested advice to those wanting to trade with the interior's many Native American tribes. Lederer added three different epilogues and a map (Cumming \& Rights 1958)26 to his third expedition journal. The first was titled, "Conjectures of the Land beyond the Apalataean Mountains" (Alvord \& Bidgood 1912, 166). Within this portion of the text, Lederer discussed his opinions about what was present beyond the Appalachian Mountains. He based his theories not only on his personal experiences and discoveries, and also upon discoveries made by others. For instance, he stated, "They are certainly in great error, who imagine that the continent of North-America is but eight or ten days journey over from the Atlantick to the Indian ocean: which all reasonable men must acknowledge, if they consider that Sir Francis Drake kept a west-northwest course from Cape Mendocino to California" (Alvord \& Bidgood 1912, 166). It was not until here in his epilogues however that Lederer finally conceded the fallacy of the idea that the East India Sea was two weeks horse travel from Virginia.

Lederer added his knowledge to the information gathered by previous explorers and Native Americans, and used that to further theorize about the western Virginia region. He stated, "what I gathered from the stranger Indians at Akenatzy of their voyage by sea to the very mountains from a far distant northwest country, I am brought over to their opinion who think that the Indian ocean does stretch an arm or bay from California into the continent as far as the Apalataean mountains, answerable to the Gulfs of Florida and Mexico on this side" (Alvord \& Bidgood 1912, 166). What Lederer did not know is

\footnotetext{
${ }^{26}$ Lord Talbot had a map of Lederer's travels, hand drawn by Lederer, published in England in 1672. It was included in a 1676 atlas of the colonies in North America, and continued to be used in such reference texts until the mid eighteenth century (Cumming and Rights 1958).
} 
that the Native American "strangers" he saw at Akenatzy could have traveled over a large river such as the Mississippi or over a large lake such as Lake Superior or Lake Erie (which Lederer did not know existed).

While there was a large amount of exploration of the North American continent done by Europeans at the time, it was a segmented system. The English, Germans, and Dutch inhabited most of the East Coast (excepting Spanish Florida); the Spanish controlled the Mississippi and its delta, California, Texas, and Mexico; and the French had a firm stake in Canada and part of the north and Midwest. One cannot fault Lederer for not knowing about the Great Lakes or the Mississippi River considering the European superpowers would not likely have shared information with one another about the regions they controlled. It was highly likely that the "stranger" Native Americans that Lederer met at Akenatzy had come from a tribe that lived on the far northwest side of the Great Lakes.

In addition, Lederer did not believe other international explorers' reports. When it was stated that there were large navigable rivers on the western side of the Appalachians, Lederer was skeptical. He firmly believed that North America was similar to South America in its topography, and that large rivers ran from west to east from the mountains, but no large rivers ran from the eastern Appalachians to the west. He explained, "the knowledge and experience we already have of South-America, whose Andes send the greatest rivers in the world (as the Amazones and Rio de la Plata, etc.) into the Atlantick, but none at all into the Pacifique sea" (Alvord \& Bidgood 1912, 166). Though this idea seemed credible, it was not so. Many navigable rivers (the Ohio, the Kanawha, etc.) run east to west from Appalachian Mountains. Lederer however, was a scientist and a 
skeptic. He needed evidence to support a fact. He believed only his own observations, and formed his theories based on what he found in his own expeditions.

Another reason given by Lederer's "no western rivers" theory was that, "all our waterfowl which delight in lakes and rivers, as swans, geese, ducks, etc., come over the mountains from the Lake of Canada, when it is frozen over every winter, to our fresh rivers; which they would never do, could they find any on the other side of the Apalataeans" (Alvord \& Bidgood 1912, 166). In addition, Lederer follows with a claim that all the waterfowl fly east of the Appalachians in the winter to escape the cold. Lederer did not know the population of waterfowl in North America, and did not know that all of the waterfowl were making winter homes east of the Appalachian Mountains. The technology of 1672 did not allow for such theories to be validated, but this conjecture by Lederer might make him seem obtuse in his reasoning. However, what must be taken into account are the types of birds and their migratory patterns that Lederer would have been able to observe. In Virginia, he would have seen the same birds migrate in and out with the seasons, and it is possible that he discovered the same type of birds spent their summers in Canada. This concept of migratory behavior, though Lederer did not call it such, makes him seem more like a learned man who reasoned scientifically rather than an insipid fool adventurer. As for Lederer's ignoring the reports of westward flowing rivers, he may have been hesitant to accept accounts by Spanish and French explorers due to a belief that they might be engaging in informational sabotage. Sir Francis Drake, an Englishman, was trustworthy. For Lederer, Spanish explorers (such as De Soto) were not. 
A second epilogue to Lederer's expedition journals is titled, "Instructions to such as shall march upon Discoveries in the North American Continent" (Alvord \& Bidgood 1912, 166). Within this section, Lederer discussed the mountain passages, necessary supplies, Native American customs regarding visitors, and the size and makeup of the expeditions. For example, Lederer stated,

Two breaches there are in the Apalataean mountains, opening a passage into the western parts of the continent. One, as I am informed by the Indians, at a place called Zynodoa [Shenandoah], to the northward; the other Sara, where I have been my self: but the way thither being thorow a vast forest, where you seldom fall in to any road or path, you must shape your course by a compass; though some, for want of one, have taken their direction from the north-side of the trees, which is distinguished from the rest by quantities of thick moss growing there. (Alvord \& Bidgood 1958, 167)

This portion of the text makes several points. First, Lederer knew about other directions by talking to the Native Americans, and he made sure to credit his source of this information. Two, Lederer continued to inform the masses how to traverse the mountainous region--either with or without a compass. This information was important not only for traveling traders and expeditions, but it was also valuable to future settlers of the western mountains of Virginia.

Lederer stated that it was very easy to get through the wilderness on horseback except where the large rivers existed. Traveling over them was time consuming and dangerous because it was necessary to build a bridge out of trees to cross them. Lederer advised that future travelers into the region travel in a group (numbering no more than six to ten), and that the majority of them be Native Americans. This was because the Native American tribes the expedition would meet were very hostile toward the Europeans and attacked them when they traveled in large groups. However, an expedition with a high 
Native American-to-European ratio would be courteously received and not be threatened by the tribes they met. In addition to information concerning the makeup of the expedition, he also gave exploration advice. He advised the marking of trees in a country where there were not discernable landmarks, in order that the expedition team would be able to find their way back (Alvord \& Bidgood 1912, 166-8).

As per supplies, future expeditions were advised to invest in cornmeal (known as Indian wheat), which was seasoned with salt and eaten. The cornmeal was more portable and "more strengthening" than regular biscuits, and did not mold as quickly. In addition to cornmeal, Lederer suggested a good gun and shot, as the wild lands were full of "fallow" and "red deer" (Alvord 1912, 168), and wild fowl such as turkeys, pigeons, and pheasants. He also suggested barbecuing and drying some of this meat before reaching the mountains, as no game was ever found on them other than bears. In addition to food, Lederer suggested either sleeping on the ground or hanging a hammock in the trees, which he stated were, "more cool and pleasant than any bed whatsoever" (Alvord \& Bidgood 1912, 168). Lederer was at home in the wilderness. His profession as an expedition leader matched his disposition as a person who loved nature and the wilderness. The Native American way of life was inviting to Lederer, but not all Virginia colonists found the Native Americans or their way of life attractive. In fact, some wanted them to be exterminated completely. They were not valued as people, but seen as savages and obstructions to colonization.

Lederer found Native Americans useful in his expeditions, but most Virginians did not respect Native American tribes. In fact, one prominent obstacle in the creation of English social order in Virginia was its large population of Native Americans. At first, it 
seemed the Virginians could exist amicably with their Native American neighbors - but it was always not to be so. The Native Americans in Virginia grew increasingly wary of the English settlers, and both sides became ever more vigilant and distrustful of the actions of the other. It was only a matter of time before the Native Americans and the European settlers would be at each other's throats. The land the Native Americans lived on was a valuable commodity of the Virginia colony. The colony's economy was dependent upon the settlement of the western mountains of Virginia, and the Native Americans were an obstacle to that colonization.

The subjugation of the Native Americans in Eastern Virginia was completed through the leadership of Berkeley. Berkeley ordered the implementation of many key colonial policies, including the construction of forts. One of these, Fort Henry (present day Petersburg, VA), became an outpost for Lederer's expeditions into the western mountains of Virginia. These later expeditions would gather the knowledge necessary to empower the colony of Virginia with the ability to gain control over the territory of the western Virginia mountains.

One way that the colony enforced its Native American policies was by building forts. These forts were important stops for the expeditions into western Virginia. At the forts, such as Fort Appomattox, Lederer and other expedition leaders acquired Native American guides and provisions. The Native American guides were important parts of every expedition, and Lederer would never left home without one (or three). In his epilogues, Lederer suggested that one or two Native American scouts travel ahead of the expedition, but for them to stay within sight of the group. By doing this, they would be 
able to not only thwart ambushes by Native Americans or other Europeans, but also gather wild game for the expedition to eat (Alvord \& Bidgood 1912).

The other Native Americans, Lederer stipulated, should surround the Europeans on both sides, and they should be armed with guns, bills, ${ }^{27}$ and hatchets. These weapons were not only for protection, but also for the procurement of boughs and bark of trees to build shelter (Alvord \& Bidgood 1912). During the night, it was necessary to build great fires around the campsite to keep the wild beasts away (such as wolves and mountain lions), and to "purifie the air." It was also advisable to make a security sweep of the camp at dusk and around dawn, for that was when the Native Americans would attack. Lederer claimed that they never attacked in the middle of the night (Alvord \& Bidgood 1912, 169).

Native American towns were also discussed. When approaching a strange Native American town, Lederer wrote that it was necessary to determine via the scouts whether or not they were friendly with the Sasquesahanaughs. If that was true, then the expedition should announce itself by shooting a rifle. If that was not true, shooting a rifle could cause the Native American tribe to attack the expedition (Alvord \& Bidgood 169). When the expedition entered the village, it was advised that no one enter a house unless they were invited, and it was customary to be led into the village like a prisoner. Also, senior members of the tribe were to be regarded above those of the younger members of the tribe, and the expedition was to refuse nothing (food or otherwise) that it was offered. To refuse anything was disrespectful to the host, and the Native Americans were very sensitive to this (Alvord \& Bidgood 1912, 169). These customs were the practices that

\footnotetext{
${ }^{27}$ A billhook or pike type of weapon, basically a spear.
} 
Lederer himself encountered from the Native American towns. It is possible that other tribes in the Appalachians reacted differently to strangers. However, it must be noted that Lederer had made these recommendations based upon what he had experienced himself.

The third epilogue, titled Touching Trade with Indians, dealt with setting up trade with the Native Americans. Lederer wrote that the neighboring Native Americans were a good market in which to trade for "skins of deer, beaver, otter, wildcat, fox, racoon, etc." (Alvord \& Bidgood 1912, 169). In order to procure these from the Native Americans, the best trading item to have in your possession was a bolt of "trading cloth, of which a yard and a half makes a matchcoat or mantle fit for their wear." Other good trade items included, "axes, hoes, knives, sizars (scissors), and all sorts of edg'd tools" (Alvord \& Bidgood 1912, 169-70). Lederer added that the Native Americans would "greedily trade" for guns and ammunition, but that it was illegal to sell or trade guns to Native Americans "within all English governments" (Alvord \& Bidgood 1912, 170). After mentioning the items to use for trade, Lederer lectured on how to trade with the Native Americans.

A trader had to be firm in the price, because if the trader lowered the price at all then the Native American would try to get it even lower. Once that happened, the deal would never happen. However, it was sometimes possible to give the Native American brandy or some type of alcohol and they would stop trying to bargain. Sometimes they would pay the trader ten times the amount of the item if they were intoxicated. However, Native Americans were also very astute and often would not bargain with a trader they knew had a history of intoxicating Native Americans in order to exploit them. The news 
of the criminal trader would spread throughout the tribes, and the Native Americans would never trade with him again (Alvord \& Bidgood 1912).

Remote tribes of Native Americans would require other goods for trade. Lederer wrote that they traded for "small looking-glasses, pictures, beads and bracelets of glass, knives, sizars (scissors), and all manner of gaudy toys and knacks for children, which are light and portable" (Alvord \& Bidgood 1912, 170). The Native American currency was not always trading with furs. Lederer wrote that the Native Americans would pay "either with their currant coyn (current coin, i.e. currency) of small shells, which they call roanoack or peack, or perhaps with pearl, vermilion, pieces of christal, and towards Ushery, with some odde pieces of plate or buillon (bullion) which they sometimes receive in truck (trade) from the Oestacks." Lederer purchased some raw silver ore from the Ushery tribe, and he claimed he bought them to prove his account of visiting them on his second expedition (Alvord \& Bidgood 1912, 170). The different types of trade items the Europeans received from Native Americans would have been used as trading pieces later among other tribes.

Lederer actually expressed regret concerning his trade experiences among the Native American tribes he met. He wrote that had he known about the wealth to be had, he would have gone better equipped with trade goods in order to gain more from the trip. He second guessed himself, though, and wrote that perhaps it was better that he had not taken more trade goods. He deduced that if he had been traveling with a large quantity of trade goods or wealth with him, he would have been attacked and killed for it. At the end of the third epilogue to his third and final expedition journal, Lederer wrote, "It is vain for any man to propose to himself, or undertake a trade at that distance, unless he goes 
with strength to defend, as well as an adventure to purchase such commodities: for in such a design many ought to joyn and go in company" (Alvord \& Bidgood 1912, 170). This advice was apt-Lederer knew the value of having Native American and military support on an expedition. The colonial population needed to feel safe before it would be ready to create revenue. Safe and viable trade markets, after all, were the goal.

\section{Conclusion}

The British Government of the late 1600s knew that colonization attempts in North America were expensive in time, money, and human lives. At this time, North America was still a vast land filled with untamed forests, wild beasts, hostile Native Americans, and other unknown dangers (Talpalar 1960). In addition to these threats, there were challenges such as climate, disease, and starvation that caused many colonies to fail. The powerful English economy, when faced with a New World to colonize, found it difficult to do so. Many of the politicians of the time were uneasy about taking on such a risky business venture. Enter Lederer-

John Lederer's texts reflected not only how the Virginia society functioned at this point in history, but also how it became a powerful economic force. It was possible to see not only what was lost, but also what was gained. By studying the documents of his time, it was possible to see the fledgling colony of Virginia grow from the Tidewater into an economic power. Without John Lederer and those like him, the colony of Virginia would never have been. Lederer's three expedition journals showed the British government the commodities and value of the land in western Virginia. The land held considerable wealth in furs, minerals, and trade among the native peoples. In addition, there was plenty of unsettled land within the territory. This land would not only produce 
goods for the market, but the future settlements in that region would produce a viable market system for the sale and trade of English commodities on the frontier. Initially, there was interest in a travel route through the Appalachian region to Asia. In Lederer's record of his first expedition, it is apparent how difficult finding that route was going to be.

Though the short route to the East India Sea proved elusive, the colony of Virginia still benefited greatly from the expeditions of John Lederer. The final result of the expeditions was the creation of a colony out of wilderness. Within that colony lived people from many parts of Europe, and who came to Virginia with one goal--to own land. What had once been a remote, wild, desolate "waste" land had become the home of those who had been tossed away as "waste" people (Sweet 2003, 401). ${ }^{28}$ The yeoman culture, the Native Americans, the Scotch-Irish, the Germans, the French, the British, and other cultures each gave a piece of themselves to the future of western Virginia.

In addition, Lederer's three expedition journals showed a minute portion of the information gathered by expeditions of the colonial period in Virginia. Lederer portrayed an in-depth appreciation and knowledge of the region and peoples he encountered, and he was very willing to share that information with the world. Although some may dispute the validity of Lederer's route or his observations, the texts' worth as a social record is incalculable. In his expedition journals, Lederer recorded the atmosphere of the time. Some of the Native American tribes he mentioned were gone fifty years later. Animals, such as the elk and the buffalo, were gone from the region within a century. And

\footnotetext{
${ }^{28}$ England found an outlet for its surplus products that had saturated the Old World markets, and its large population of "waste" people (criminals, the poor, etc.). The process of colonizing Virginia then changed the products and people from a drain on society into revenue-producing commodities. In addition, they
} 
Lederer's own story--that of a German citizen in a colony prejudiced against him--was part of a world that vanished centuries ago. More importantly, the studies of Lederer's texts have shown the immensity and complexity of a colony's creation. It was through Lederer, and men like him, that the colony of Virginia was able to create a commonwealth out of wilderness.

were creating not only a new English social order, but creating products that England hoped would replace those from other parts of the world (Sweet 2003). 


\section{Reference List}

Adams, Stephen. 2001. The Best \& Worst Country in the World: Perspectives on the Early Virginia Landscape. Charlottesville, Va.: University Press of Virginia.

Alvord, Clarence Walworth and Lee Bidgood. 1912. The First Explorations of the Trans - Allegheny Region by the Virginians 1650-1674. Cleveland: The Arthur H. Clark Company.

Buckley, Geoffrey L. 2004. Extracting Appalachia: Images of the Consolidation Coal Company, 1910-1945. Athens, OH: Ohio University Press.

Cumming, William P. and Douglas L. Rights. 1958. The Discoveries of John Lederer with Unpublished Letters by and about Lederer to Governor John Winthrop, Jr. and an Essay on the Indians of Lederer's Discoveries. Charlottesville, VA: University of Virginia Press.

De Hass, Wills. 2000. History of the Early Settlement and Indian Wars of West Virginia: An Account of the Various Expeditions in the West, Previous to 1795. McClain Printing Company: Parsons, WV.

Drake, Richard B. 2001. A History of Appalachia. Lexington, KY: The University Press of Kentucky.

Savage Jr., Henry. 1979. The New American Nation Series: Discovering America 17001875. New York: Harper \& Row Publishers.

Sweet, Timothy. 2003. "Economy, Ecology, and Utopia in Early Colonial Promotional Literature". From the Fallen Tree: Frontier Narratives, Environmental Politics, and the Roots of a National Pastoral. Thomas Hallock, Ed. Chapel Hill and London: University of North Carolina Press. 
Talpalar, Morris. 1960. The Sociology of Colonial Virginia. New York: Philosophical Library, Inc. 